\title{
Construction Industry 4.0 and Sustainability: An Enabling Framework
}

\author{
Sreejith Balasubramanian, Vinaya Shukla, Nazrul Islam*, and Shalini Manghat
}

\begin{abstract}
Governments worldwide are taking actions to address the construction sector's sustainability concerns, including high carbon emissions, health and safety risks, low productivity, and increasing costs. Applying Industry 4.0 technologies to construction (also referred to as Construction 4.0) could address some of these concerns. However, current understanding about this is quite limited, with previous work being largely fragmented and limited both in terms of technologies as well as their interrelationships with the triple bottom line of sustainability perspectives. The focus of this study is therefore on addressing these gaps by i) proposing a comprehensive multidimensional Construction 4.0 sustainability framework that identifies and categorizes the key Construction 4.0 technologies and their positive and negative impacts on environmental, economic, and social sustainability, and then ii) establishing its applicability/usefulness through an empirical, multi-methodology case study assessment of the UAE's construction sector. The findings indicate Construction 4.0's positive impacts on environmental and economic sustainability far outweigh its negative effects, though these impacts are comparable with regards to social sustainability. On Construction 4.0 technologies itself, their application was found to be non-uniform, with greater application seen for building information modeling and automation vis-à-vis others such as cyber-physical systems and smart materials, with significant growth expected in the future for blockchain- and 3D-printing-related technologies. The proposed novel framework could enable the development of policy interventions and support mechanisms to increase Construction 4.0 deployment while addressing its negative sustainability-related impacts. The framework also has the potential to be adapted and applied to other country and sectoral contexts.
\end{abstract}

Index Terms - Industry 4.0, Construction 4.0, sustainability framework, environmental sustainability, social sustainability; economic sustainability, UAE

\section{INTRODUCTION}

$\mathrm{W}$ ITH more than two-thirds of the world's population expected to live in urban areas by 2050 , the construction industry is expected to play a critical role in the economic development of most countries (Balasubramanian and Shukla, 2017a). However, it has traditionally been low-tech with significant reliance on craft-based methods and is associated with poor performance and quality (Craveiro et al., 2019). Its

This paragraph of the first footnote will contain the date on which you submitted your paper for review. It will also contain support information, including sponsor and financial support acknowledgment. For example, "This work was supported in part by the U.S. Department of Commerce under Grant BS123456."

S. Balasubramanian is with the Business School, Middlesex University Dubai, PO Box 500697, Dubai, UAE (e-mail: s.balasubramanian@mdx.ac.ae). productivity has remained nearly flat for the last several decades, and part of the reason has been its conservative approach to project design and delivery (Reinhardt et al., 2020). This slow pace of innovation matters because of the industry's significant negative economic (e.g., low-profit margins, significant project delays, and budget overruns), environmental (e.g., high resource, energy, and water consumption and waste generation; accounts for $30 \%$ of the world's greenhouse gas emissions as per Craveiro et al., 2019) and social (e.g., high worker deaths/injuries, poor working conditions) impacts (Balasubramanian and Shukla, 2017a; Calvetti, 2020a; Turner et al., 2020; You and Feng, 2020).

Industry 4.0 technologies (referred to as Construction 4.0 for the construction sector) that are enabled by data, digital technologies, and automation have gained momentum in academic, managerial, and policy circles in recent times (Beltrami et al., 2021). While they are seen as a solution to address the sector's sustainability-related challenges (e.g., reducing material usage and waste with $3 \mathrm{D}$ printing of buildings), there are also significant concerns about their adverse effects, such as increased energy requirements and job losses (Chan, 2020). However, unfortunately, the previous literature is unable to provide much clarity on the relationship between Construction 4.0 and sustainability. For instance, a recent literature-review-based study on Industry 4.0 and sustainability by Beltrami et al. (2021) did not find any studies on construction. Similarly, other studies that have discussed sustainability in relation to Construction 4.0 (e.g., Sherratt et al., 2020; Calvetti et al., 2020) have largely focused on social sustainability rather than taking a triple bottom line (TBL) perspective, in which economic, environmental, and social elements are considered together. A TBL perspective is important as the different sustainability impacts from Construction 4.0 technologies could conflict with each other. For example, blockchain could improve operational efficiency and reduce costs (greater economic sustainability) but also increase the energy requirement that is needed to power the associated algorithms (lower environmental sustainability) (du Plessis and Sherratt, 2020).

Another weakness of these studies is that most of them are

V. Shukla is with the Business School, Middlesex University London, London NW4 4BT, United Kingdom (e-mail: v.shukla@mdx.ac.uk)

N. Islam is with Business School, University of Exeter, Exeter EX4 4PY, United Kingdom (e-mail: N.Islam@exeter.ac.uk)

S. Ajayan is with Mohammed Bin Rashid School of Government, P.O. Box 72229, Dubai, UAE (e-mail: shalini.ajayan@mbrsg.ac.ae) 
also desk discourse analysis based (Chan, 2020; du Plessis and Sherratt, 2020) or secondary review based (Ibrahim et al., 2019; Akyazi et al., 2020); first-hand empirical insights are sadly missing. Finally, even without the sustainability aspect, knowledge of Construction 4.0 technologies itself is quite limited; most studies have narrowly focused on one or a few technologies (e.g., Ibrahim et al. (2019) on Building Information Modeling (BIM) and Reinhardt et al. (2020) and Moon et al. (2020) on robotic technology), though there have been some recent attempts at a more comprehensive approach (e.g., Newman et al., 2020; Zabidin et al., 2020; and Forceal et al., 2020). Overall, this means that there are significant knowledge gaps that could hamper Construction 4.0's largescale acceptability and implementation both technology-wise as well as vis-à-vis its sustainability impacts.

These gaps suggest the need for a comprehensive enabling framework that, in turn, can facilitate an associated empirical investigation. The specific research objectives of this study are, therefore:

- To identify and integrate various isolated Construction 4.0 technologies into meaningful and managerially relevant categories

- To develop a 'Construction 4.0 Sustainability Framework' that conceptualizes the interconnectedness between the various Construction 4.0 technologies and the economic, environmental, and social sustainability dimensions

- To test the applicability and usefulness of the framework in a real-world setting

While meeting the above objectives, the study seeks to answer the following research questions:

- What is the current and future state of Construction 4.0 technologies, and how are they disrupting the sector?

- What are the positive and negative implications of these Construction 4.0 technologies for the sector's environmental, economic, and social sustainability?

This required, first, a systematic review of the (scattered) Construction 4.0 studies to develop the framework, followed by testing the framework's applicability and usefulness through an empirical, multi-methodology case study. The United Arab Emirates (UAE)'s construction sector was used as the research setting, because the construction intensity there is high, and the country is also associated with some of the most innovative buildings and projects globally (Balasubramanian and Shukla, 2017a). The UAE is also strongly committed to realizing high economic, social, and environmental sustainability outcomes (Vision 2021, 2019). It is also at the forefront of using innovative technologies in the construction sector (Dulaimi, 2021). UAE's construction sector, therefore, provides an appropriate setting to assess opportunities and challenges associated with Construction 4.0 and sustainability.

The study makes a significant contribution. It is the first comprehensive empirical investigation to link Construction 4.0 with economic, environmental, and social sustainability dimensions. The study framework and the case study findings, therefore, are both novel and significant. Though UAE's construction sector is used as the case context, the fact that other advanced countries' construction sectors are similar means that insights from this study can be applied elsewhere. This also includes the framework, the conceptual comprehensiveness of which enables it to be suitably adapted and applied to other country and sectoral contexts.

The rest of the paper is structured as follows. In the next section, we outline the research framework used. In Section 3, the literature review leading to the Construction 4.0 sustainability framework development is discussed. The research setting and the case study method used to evaluate the framework's applicability are detailed in Section 4. The case study findings are discussed in Section 5. We conclude in Section 6 with the study implications, limitations, and suggestions for future work.

\section{RESEARCH FRAMEWORK}

The research framework adopted in this study is given in Fig. 1 below, which can be seen to have two main stages: 1) The literature review stage of developing the 'Construction 4.0 Sustainability Framework', and 2) The case study of UAE's construction sector stage to test the framework's applicability and usefulness. These are discussed in detail in the following sections.

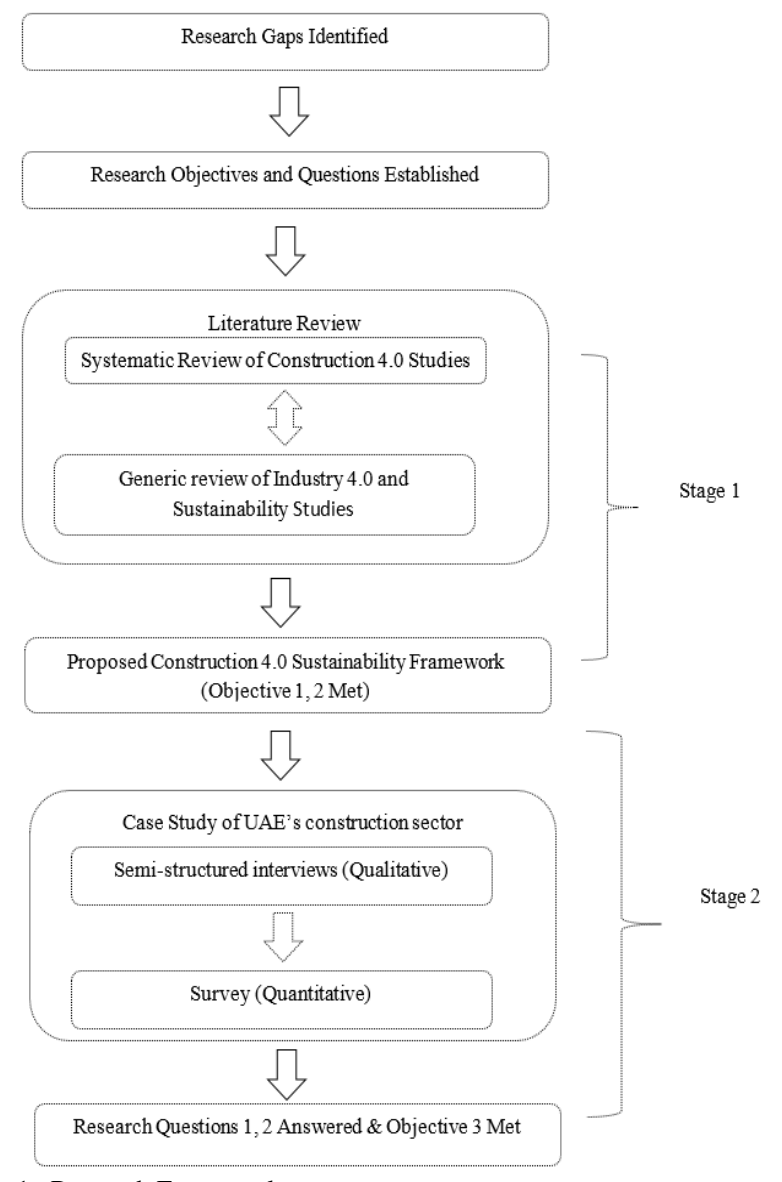

Fig. 1. Research Framework

\section{LITERATURE REVIEW AND FRAMEWORK DEVELOPMENT}

The literature review involved a systematic review of Industry 4.0 studies in the construction sector or Construction 
4.0 followed by a generic review of studies that explored the link between Industry 4.0 and sustainability.

\section{A. Systematic Literature Review of Construction 4.0}

The objective of the systematic review was twofold. The first objective was to identify and integrate the various isolated Construction 4.0 technologies disrupting the sector. The second objective was to synthesize the positive and negative impacts of Construction 4.0 technologies on the environmental, economic, and social sustainability dimensions. The systematic review was undertaken using the Scopus database because of its broad coverage of journals. The keywords used to identify the initial list included "industry 4.0" AND "construction" OR "Construction 4.0" OR “industry 4.0" AND "building." In order to ensure rigor and quality, conference proceedings, working papers, and book chapters were excluded.

The initial search identified over 1000 studies. After removing duplicates and limiting the studies to only articles from peer-reviewed academic journals, the list was narrowed to 387 articles. The articles were then screened on the basis of their title and abstract, and only those with a primary focus on construction and Industry 4.0 were shortlisted. A brief content (full-text) review of these articles was carried out to exclude studies that are too technical, such as those on modeling, simulation, Industry 4.0 architecture, and algorithms (e.g., Tahmasebinia et al., 2020). Also, articles published in leading construction journals such as the Journal of Construction Engineering and Management, and International Journal of Construction Management were checked to ensure there are no important omissions. Finally, references cited in the shortlisted studies were also reviewed to identify additional articles, leaving 29 studies on Construction 4.0 for detailed analysis. Fig. 2 summarizes the systematic review process followed.

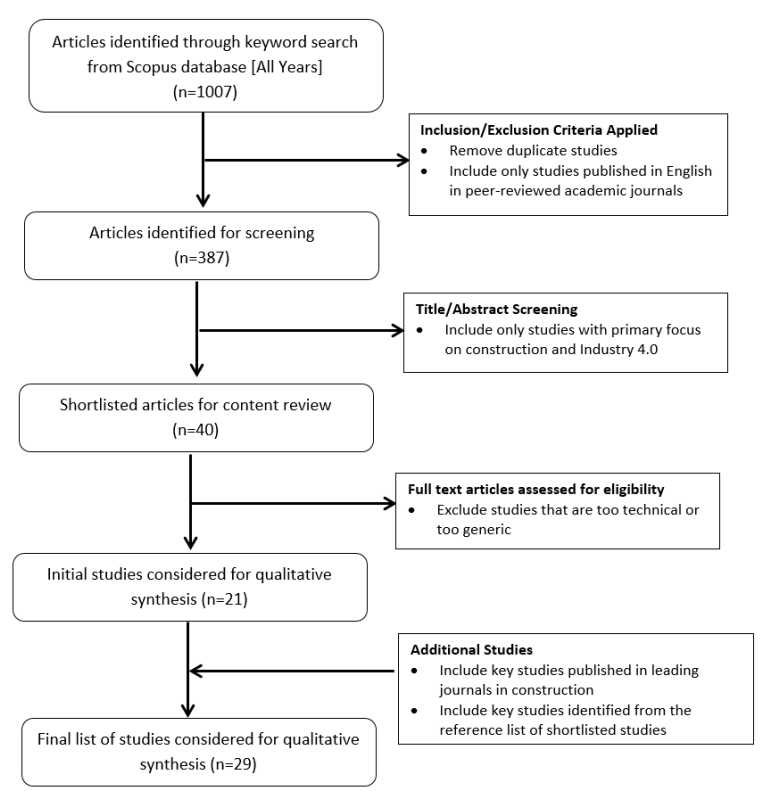

Fig. 2. Systematic Review of Construction 4.0

Our syntheses of the shortlisted studies (Table I) revealed several gaps. First and foremost, most of these studies are narrow in scope, focusing on one or just a few specific technologies; for example, Sacks et al. 2020) have focused on Digital Twins, while Ahmed (2018) has focused on augmented and virtual reality technologies. Next, studies have made little effort to explicitly link Construction 4.0 with the various dimensions of sustainability. Most studies have explored or discussed Construction 4.0 and sustainability aspects as an auxiliary concern rather than the main topic. Also, these studies have mostly covered only some aspects of Industry 4.0 and sustainability (as well as failing to cover all of their interrelated dynamics). As evident from Table I, very few studies have simultaneously discussed the Construction 4.0 impact on all three dimensions of sustainability. In many cases, the primary focus is on the social sustainability dimension, so a balanced perspective based on the triple bottom line concept is missing. Further, most studies are either descriptive or conceptual and are based on secondary data or literature review. Empirical investigation to gain first-hand insights into different aspects of Construction 4.0 via interviews and/or case studies and/or surveys appears to be limited. Overall though, despite these gaps, the synthesis of the studies in Table I provided the conceptual base for the development of the Construction 4.0 sustainability framework; it enabled us to understand the key Construction 4.0 technologies disrupting the sector and their implications for the TBL sustainability dimensions.

\section{B. Review of Generic Studies on Industry 4.0 and Sustainability}

Despite their differences, the construction sector could still benefit from "borrowing" innovative ideas and technologies from other sectors, provided they are carefully assessed and contextualized (Balasubramanian and Shukla, 2017). The objective of this generic review was threefold. First, the review sought to ensure that there are no important omissions of technologies relevant to construction within the larger body of Industry 4.0 literature, especially those from high application sectors such as manufacturing. Second, the review sought to critically examine the studies that have explicitly examined the link between Industry 4.0 and the TBL of sustainability (e.g., Beltrami et al., 2021), including from both the problems and the opportunities perspectives. Finally, the review was undertaken to gain insights into the thematic classification of Construction 4.0 technologies into meaningful and managerially relevant categories. Table II summarizes the key studies on Industry 4.0 and Sustainability identified from the generic literature.

The following insights were gained from the literature review. With the exception of a few new but related technologies such as hologram and cloud manufacturing, the key technologies identified in Table I (Construction 4.0) and Table II (Industry 4.0) are similar. This assured that we have not missed out on any key Industry 4.0 technologies relevant to construction. However, unlike Construction 4.0 literature, the generic literature is more mature in examining the direct relationship between Industry 4.0 and TBL of sustainability. Studies have examined the direct impact of Industry 4.0 on on different stages of the product/ project life-cycle, starting from sustainable design, procurement, manufacturing/ 
TABLE I

SUMMARY OF STUDIES ON CONSTRUCTION 4.0

\begin{tabular}{|c|c|c|c|c|}
\hline Study & Country & Methodology & Primary Focus & $\begin{array}{c}\text { Construction } 4.0 \\
\text { technologies considered }\end{array}$ \\
\hline $\begin{array}{l}\text { Ahmed } \\
(2018)\end{array}$ & Generic & $\begin{array}{l}\text { Literature } \\
\text { review }\end{array}$ & $\begin{array}{l}\text { Opportunities for } \mathrm{AR} \\
\text { and VR in } \\
\text { construction }\end{array}$ & $\begin{array}{l}\text { Virtual Reality (VR), } \\
\text { Augmented Reality (AR) }\end{array}$ \\
\hline
\end{tabular}

Key findings

(Implications on sustainability)

Economic Implication: Reduction in overall

project costs; Improvement in tracking and

scheduling; timely access to project information;

reduction in labor hours; reduction in data

acquisition costs; reduction in employee training

costs; reduction in maintenance and facilities

management costs; improvement in quality;

reduction in project completion time

Social Implication: Provide virtual and augmented training to enhance workers safety; detect defects, risks, and accidents before they even occur; reduces the need for manpower by automating a number of site inspection processes and defect management processes

\begin{tabular}{|c|c|c|c|c|}
\hline $\begin{array}{l}\text { Dallasega } \\
(2018)\end{array}$ & Italy & $\begin{array}{l}\text { Multiple case } \\
\text { studies }\end{array}$ & $\begin{array}{l}\text { Industry } 4.0 \text { for } \\
\text { improving } \\
\text { construction supply } \\
\text { chain }\end{array}$ & $\begin{array}{l}\text { Building Information } \\
\text { Modeling (BIM); Cloud } \\
\text { Computing; Internet of } \\
\text { Things (IoT); Cyber- } \\
\text { Physical Systems (CPS); } \\
\text { Big Data; AR; VR; } \\
\text { Geographical Information } \\
\text { Systems (GIS) }\end{array}$ \\
\hline
\end{tabular}

Environmental implications: Increase in carbon emissions due to increase in transportation from Just-in-Time (JIT) deliveries

Economic implications: Improvement in the process; reductions in lead time, late and early deliveries, wasteful intermediate storage, inventory levels; increases in transportation costs and costs associated with reorganizing existing processes

\begin{tabular}{lllll}
\hline $\begin{array}{l}\text { Cai et al. } \\
\text { (2019) }\end{array}$ & Generic & $\begin{array}{l}\text { Scientometric } \\
\text { literature } \\
\text { review, } \\
\text { critical } \\
\text { literature } \\
\text { review and } \\
\text { market } \\
\text { review }\end{array}$ & $\begin{array}{l}\text { Identify the key } \\
\text { research areas and } \\
\text { practical applications } \\
\text { of automation and } \\
\text { robotics in high-rise } \\
\text { building construction }\end{array}$ & Robotics \\
& & & \\
& & Literature & $\begin{array}{l}\text { Explores the potential } \\
\text { of additive } \\
\text { manufacturing in the } \\
\text { review }\end{array}$ & Additive manufacturing \\
& & & & \\
$\begin{array}{l}\text { Craveiroa et } \\
\text { al. (2019) }\end{array}$ & Generic & & &
\end{tabular}

Economic implications: Improve efficiency,

productivity, and quality

Social Implication: Provide automated solutions to compensate for the labor shortage, reduce the number of safety risks associated with construction and maintenance of high-rise buildings such as façade cleaning, steel beam assembly, façade installation, etc.; reduction in manual jobs

Economic Implication: Reducing in production time; shorter lead times; lower inventory costs; lower supply chain costs; improvement in resource efficiency

Environmental Implications: Reduces cement consumption, thereby reducing $\mathrm{CO}_{2}$ emissions supports sustainable construction approach through the use of recycled and natural materials. Social Implication: Reduces the number of fatalities and injuries in construction sites

\begin{tabular}{|c|c|c|c|c|}
\hline $\begin{array}{l}\text { de Soto et } \\
\text { al. (2019) }\end{array}$ & Switzerland & Case study & $\begin{array}{l}\text { Implications of } \\
\text { Construction } 4.0 \text { on } \\
\text { workforce and } \\
\text { organizational } \\
\text { structures }\end{array}$ & $\begin{array}{l}\text { 3D Printing; Robotic } \\
\text { Assembly }\end{array}$ \\
\hline
\end{tabular}

Social implications: Reduction in number of workers, change in nature of jobs and organizational structures, creation of new job roles

Economic implications: Reduction in project completion times; improvement in processes

\begin{tabular}{|c|c|c|c|c|c|}
\hline $\begin{array}{l}\text { Ibrahim et } \\
\text { al. (2019) }\end{array}$ & Malaysia & $\begin{array}{l}\text { Literature } \\
\text { review }\end{array}$ & $\begin{array}{l}\text { Employee skills } \\
\text { required for the } \\
\text { implementation of } \\
\text { BIM }\end{array}$ & BIM & $\begin{array}{l}\text { Social implications: Shortage of skilled workers } \\
\text { in the construction sector; the need for } \\
\text { government and private sector to come together to } \\
\text { develop education and training programs for } \\
\text { upskilling students, graduates and practitioners in } \\
\text { BIM; need for updating existing outdated } \\
\text { curricula in Universities and polytechnics. }\end{array}$ \\
\hline $\begin{array}{l}\text { Maskuriy et } \\
\text { al. (2019) }\end{array}$ & Generic & $\begin{array}{l}\text { Systematic } \\
\text { literature } \\
\text { review and } \\
\text { bibliometric } \\
\text { mapping }\end{array}$ & $\begin{array}{l}\text { Examine the state of } \\
\text { Industry } 4.0 \text { in the } \\
\text { construction sector }\end{array}$ & BIM, IoT, AR, CPS & $\begin{array}{l}\text { Environmental implications: Optimize energy } \\
\text { efficiency; waste reduction } \\
\text { Economic Implications: Reduce delays and } \\
\text { unforeseen costs; improve work quality; } \\
\text { improvement in efficiency and productivity } \\
\text { Social Implications: Improve security and safety }\end{array}$ \\
\hline $\begin{array}{l}\text { Adepoju } \\
\text { and } \\
\text { Aigbavboa } \\
(2020 a)\end{array}$ & Nigeria & Survey & $\begin{array}{l}\text { Threats and } \\
\text { opportunities to } \\
\text { construction sector } \\
\text { workforce due to } \\
\text { implementation of } \\
\text { Construction } 4.0 \\
\text { technologies }\end{array}$ & BIM; Robotics; Drones & $\begin{array}{l}\text { Social Implications: Threats - Lack of employee } \\
\text { awareness, interest, and skills; loss of jobs; } \\
\text { privacy issues; Opportunities - improvement in } \\
\text { stakeholder collaboration, relationships, and } \\
\text { employee efficiency; reduction in employee } \\
\text { fatigue } \\
\text { Economic implications: High cost of } \\
\text { implementation; lack of access to loans/finance, } \\
\text { government support }\end{array}$ \\
\hline
\end{tabular}




\begin{tabular}{|c|c|c|c|c|c|}
\hline Study & Country & Methodology & Primary Focus & $\begin{array}{c}\text { Construction } 4.0 \\
\text { technologies considered }\end{array}$ & $\begin{array}{c}\text { Key findings } \\
\text { (Implications on sustainability) }\end{array}$ \\
\hline $\begin{array}{l}\text { Adepoju } \\
\text { and } \\
\text { Aigbavboa } \\
(2020 b)\end{array}$ & Nigeria & Survey & $\begin{array}{l}\text { Knowledge and skill } \\
\text { gaps in Construction } \\
4.0\end{array}$ & $\begin{array}{l}\text { IoT; BIM; 3D printing; Big } \\
\text { Data; Prefabrication/ } \\
\text { Modularization; Cloud } \\
\text { Computing; Robotics; VR; } \\
\text { AR; CPS }\end{array}$ & $\begin{array}{l}\text { Social Implications: Good knowledge of } \\
\text { automation, IoT, BIM, 3D Printing, and Big Data. } \\
\text { Limited knowledge of CPS, robotics, VR, and } \\
\text { AR. Highest skill gap found in human-machine } \\
\text { communication, followed by data analytics, cyber } \\
\text { security, and computer programming. }\end{array}$ \\
\hline $\begin{array}{l}\text { Akyazi et al. } \\
(2020)\end{array}$ & Europe & $\begin{array}{l}\text { Secondary } \\
\text { desk research }\end{array}$ & $\begin{array}{l}\text { Current and future } \\
\text { skill requirements of } \\
\text { civil engineering for } \\
\text { construction } 4.0\end{array}$ & $\begin{array}{l}\text { BIM; IoT; 3D Laser } \\
\text { Scanning; 3D Printing; Big } \\
\text { Data Analytics; AR; VR; } \\
\text { Robotic Construction; } \\
\text { Machine Learning (ML); } \\
\text { Artificial Intelligence (AI); } \\
\text { Smart Materials; Drones; } \\
\text { Autonomous Vehicles } \\
\end{array}$ & $\begin{array}{l}\text { Social implications: Need for basic ICT literacy } \\
\text { for all future jobs; need to possess digital skills, } \\
\text { technical skills to operate the new construction } \\
4.0 \text { technologies; data analytics skills, advance } \\
\text { ICT and problem-solving skills, ability to adapt } \\
\text { and change; continuous learning; ethics; critical } \\
\text { thinking, creativity, cultural sensitivity and } \\
\text { empathy. }\end{array}$ \\
\hline $\begin{array}{l}\text { Barrett } \\
(2020)\end{array}$ & $\begin{array}{l}\text { UK } \\
\text { perspective }\end{array}$ & $\begin{array}{l}\text { Discourse } \\
\text { analysis }\end{array}$ & $\begin{array}{l}\text { Opportunities of } \\
\text { Construction } 4.0 \text { to } \\
\text { resolve issues of } \\
\text { gender equity in the } \\
\text { sector }\end{array}$ & - & $\begin{array}{l}\text { Social Implications: Reduction in gender divide } \\
\text { through increased participation of females; } \\
\text { elimination/reduction in pay disparity between } \\
\text { male and female workers. }\end{array}$ \\
\hline
\end{tabular}

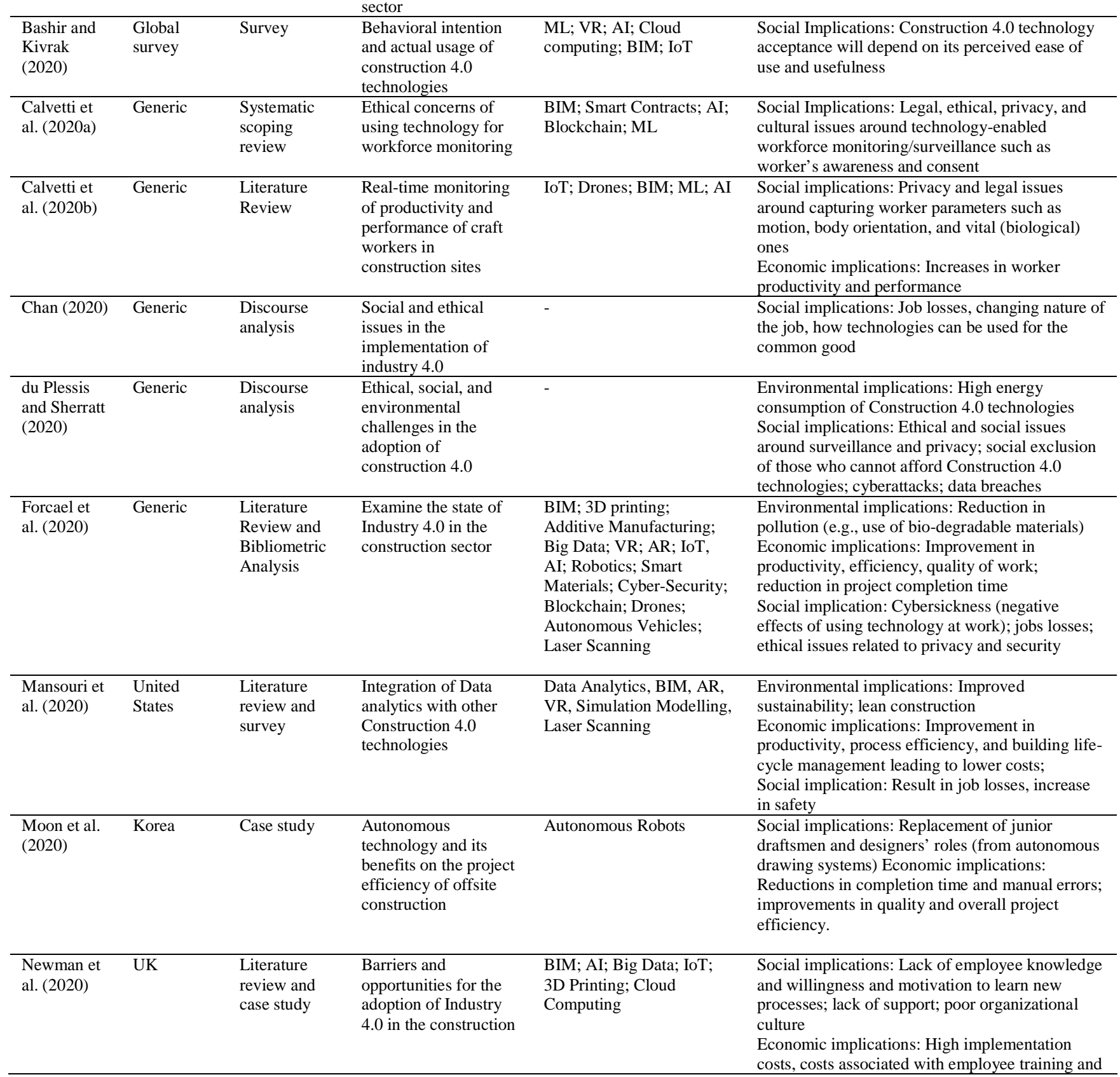




\begin{tabular}{|c|c|c|c|c|}
\hline Study & Country & Methodology & Primary Focus & $\begin{array}{c}\text { Construction } 4.0 \\
\text { technologies considered }\end{array}$ \\
\hline $\begin{array}{l}\text { Osunsanmi } \\
\text { et al. (2020) }\end{array}$ & $\begin{array}{l}\text { South } \\
\text { Africa }\end{array}$ & Survey & $\begin{array}{l}\text { Adoption of } \\
\text { Construction } 4.0 \\
\text { technologies }\end{array}$ & $\begin{array}{l}\text { Big Data; Cloud } \\
\text { Computing; AR; BIM; } \\
\text { Robotics; CPS; Drones; } \\
\text { IoT }\end{array}$ \\
\hline
\end{tabular}

\begin{tabular}{llll}
\hline $\begin{array}{l}\text { Reinhardt et } \\
\text { al. (2020) }\end{array}$ & Australia & $\begin{array}{l}\text { Survey, focus } \\
\text { group }\end{array}$ & $\begin{array}{l}\text { Potential of using } \\
\text { human-robot } \\
\text { interactions in } \\
\text { performing tasks in the } \\
\text { construction industry. }\end{array}$ \\
\hline $\begin{array}{lll}\text { Sacks et al. } \\
(2020)\end{array}$ & Generic & $\begin{array}{l}\text { Literature } \\
\text { Review } \\
\text { (Conceptual } \\
\text { Paper) }\end{array}$ & $\begin{array}{l}\text { Establish the } \\
\text { application of digital } \\
\text { twins across the full } \\
\text { life-cycle of a } \\
\text { construction project }\end{array}$ \\
& &
\end{tabular}

Collaborative Robots (CoBots)

Robotics; CPS; Drones; IoT

(Implications on sustainability)

upskilling, coordination costs across the various partnering firms in the value chain

Social implications: Lack of standards, policies;

and employee willingness to embrace new

technology;

Economic implications: High implementation cost

[High levels of adoption of drones, BIM,

prefabrication/modularization, Internet of things

and automation; least levels of adoption for

robotics and cyber physical systems]

Social implications: CoBots could be used to

work collaboratively with humans in construction tasks

Digital twins; Agent-based $\quad$ Environmental Implications: Improved production

Simulation

planning significantly reduces waste in

construction. Reliable production planning leads

to increased capacity utilization of equipment,

thereby reducing the carbon footprint

Economic Implications: Reduces manual work

(thereby saving time and eliminating errors)

required in construction progress monitoring and consequently bringing down the overall costs. Real-time monitoring of construction materials improves inventory management and reduces waiting time for resources. Less production waste leads to lower overhead costs and reduces direct construction costs

Social Implications: Eliminates a number of manual processes such as monitoring construction progress using observation and measurement. Real-time monitoring of construction sites can enable the delivery of safety alerts when workers are exposed to hazards

\begin{tabular}{|c|c|c|c|c|c|}
\hline $\begin{array}{l}\text { Sherratt et } \\
\text { al. }(2020)\end{array}$ & $\begin{array}{l}\text { UK-centric } \\
\text { perspective }\end{array}$ & $\begin{array}{l}\text { Literature } \\
\text { review and } \\
\text { discourse } \\
\text { analysis }\end{array}$ & $\begin{array}{l}\text { Ethical and social } \\
\text { consequences of the } \\
\text { implementation of } \\
\text { construction } 4.0\end{array}$ & - & $\begin{array}{l}\text { Social implications: Loss of certain jobs, creation } \\
\text { of new jobs; improved worker competencies and } \\
\text { skills through the requirement for reskilling and } \\
\text { upskilling; effect on professional autonomy of } \\
\text { practitioners; shift of power to technology } \\
\text { providers }\end{array}$ \\
\hline $\begin{array}{l}\text { You and } \\
\text { Feng }(2020)\end{array}$ & China & $\begin{array}{l}\text { Systematic } \\
\text { literature } \\
\text { review and } \\
\text { case study }\end{array}$ & $\begin{array}{l}\text { Integration of Industry } \\
4.0 \text { technologies in } \\
\text { construction sector } \\
\text { using Cyber-Physical } \\
\text { systems (CPS) }\end{array}$ & $\begin{array}{l}\text { BIM; IoT; Cloud } \\
\text { Computing; Big Data; ML; } \\
\text { VR; AR; 3D Modeling; } \\
\text { CPS; Discrete-event } \\
\text { Simulation (DES) }\end{array}$ & $\begin{array}{l}\text { Environmental implications: Improvement in } \\
\text { environmental performance } \\
\text { Social Implications: Improvement in safety } \\
\text { Economic implications: Improvement in } \\
\text { construction process, quality, and cost reduction. }\end{array}$ \\
\hline $\begin{array}{l}\text { Zabidin et } \\
\text { al. (2020) }\end{array}$ & Generic & $\begin{array}{l}\text { Literature } \\
\text { review, } \\
\text { bibliometric } \\
\text { and } \\
\text { scientometric } \\
\text { mapping }\end{array}$ & $\begin{array}{l}\text { Examining the } \\
\text { Industry } 4.0 \\
\text { technologies in the } \\
\text { construction sector }\end{array}$ & $\begin{array}{l}\text { BIM; VR; AR; Mixed } \\
\text { Reality (MR); Simulation; } \\
\text { Additive Manufacturing; } \\
\text { 3D Printing; Robotics; IoT; } \\
\text { Cloud Computing; Mobile } \\
\text { Computing; Big Data; } \\
\text { Modularization; AI; CPS } \\
\end{array}$ & $\begin{array}{l}\text { Environmental implications: Sustainable } \\
\text { development } \\
\text { Social Implications: Improvement in safety } \\
\text { Economic implications: Improvement in } \\
\text { efficiency and productivity }\end{array}$ \\
\hline $\begin{array}{l}\text { Muñoz } \square \text { La } \\
\text { Rivera et al. } \\
(2021)\end{array}$ & Generic & $\begin{array}{l}\text { Literature } \\
\text { review } \\
\text { (Conceptual } \\
\text { Paper) }\end{array}$ & $\begin{array}{l}\text { A methodological } \\
\text { Technological } \\
\text { Framework for } \\
\text { Construction } 4.0\end{array}$ & $\begin{array}{l}\text { 3D printing; ML, AI; AR; } \\
\text { VR; Big Data Analytics; } \\
\text { Blockchain; BIM, Cloud } \\
\text { Computing; CPS; IoT; } \\
\text { Prefabrication/ } \\
\text { Modularization; 3D } \\
\text { Scanning; } \\
\text { Photogrammetry; } \\
\text { Robotics; Drones; GIS }\end{array}$ & $\begin{array}{l}\text { Social Implications: Barriers to Construction } 4.0 \text { - } \\
\text { Excessive regulation limiting innovation; lack of } \\
\text { skilled workers }\end{array}$ \\
\hline $\begin{array}{l}\text { Turner et al. } \\
(2021)\end{array}$ & Generic & $\begin{array}{l}\text { Literature } \\
\text { review }\end{array}$ & $\begin{array}{l}\text { Opportunities and } \\
\text { challenges of Industry } \\
4.0 \text { in construction }\end{array}$ & $\begin{array}{l}\text { Big Data Analytics; AI; } \\
\text { Robotics; BIM }\end{array}$ & $\begin{array}{l}\text { Social implications: Enhanced safety and quality } \\
\text { of construction; data privacy issues } \\
\text { Economic implications: Increase in productivity; } \\
\text { reduction in overall costs }\end{array}$ \\
\hline
\end{tabular}


TABLE II

GENERIC REVIEW OF STUDIES EXAMINING INDUSTRY 4.0 AND SUSTAINABILITY

\begin{tabular}{|c|c|c|c|c|}
\hline Study & Country & Methodology & Primary Focus & $\begin{array}{c}\text { Construction } 4.0 \\
\text { technologies considered }\end{array}$ \\
\hline $\begin{array}{l}\text { Morrar et } \\
\text { al. (2017) }\end{array}$ & Generic & $\begin{array}{l}\text { Discourse } \\
\text { analysis }\end{array}$ & $\begin{array}{l}\text { Proposed an Industry } \\
4.0 \text { framework to } \\
\text { achieve TBL } \\
\text { sustainability through } \\
\text { technological and } \\
\text { social innovation }\end{array}$ & $\begin{array}{l}\text { Industry } 4.0 \text { technologies } \\
\text { in general }\end{array}$ \\
\hline $\begin{array}{l}\text { Kamble et } \\
\text { al. (2018) }\end{array}$ & Generic & $\begin{array}{l}\text { Systematic } \\
\text { literature } \\
\text { review and } \\
\text { bibliometric } \\
\text { analysis }\end{array}$ & $\begin{array}{l}\text { Proposed a Sustainable } \\
\text { Industry } 4.0 \\
\text { framework to examine } \\
\text { current trends and } \\
\text { future perspectives }\end{array}$ & $\begin{array}{l}\text { IoT; Big Data; Cloud } \\
\text { Computing; Cloud } \\
\text { Manufacturing; 3D } \\
\text { Printing; AR; Robotics; } \\
\text { Cyber-Security }\end{array}$ \\
\hline
\end{tabular}

Key findings
(Implications on sustainability)
Social Implications: Job losses due to substitution
of human roles by automation and digitization; the
need for employee upskilling and reskilling
privacy concerns
privacy concerns

Environmental Implications: Reduction in waste; water; energy; raw materials Economic Implications: Cost-optimized global production systems; reduced total cost of ownership using improved predictive maintenance, reduced product development costs, improved purchasing decisions, and customized on-demand manufacturing. Social Implications: Improved and safe working conditions for employees

\begin{tabular}{|c|c|c|c|c|c|}
\hline $\begin{array}{l}\text { Oztemel } \\
\text { and Gursev } \\
(2018)\end{array}$ & Generic & $\begin{array}{l}\text { Literature } \\
\text { review }\end{array}$ & $\begin{array}{l}\text { Examining the state of } \\
\text { Industry } 4.0 \\
\text { technologies and their } \\
\text { potential benefits }\end{array}$ & $\begin{array}{l}\text { Location Detection } \\
\text { Technologies; IoT; Cloud- } \\
\text { based Systems; Big Data } \\
\text { Analytics; AR, Advanced } \\
\text { Algorithms (ML and AI); }\end{array}$ & $\begin{array}{l}\text { Economic Implications: Improvement in } \\
\text { efficiency, quality, resource utilization; } \\
\text { adaptability; flexibility; reduction in delays } \\
\text { Social Implications: Create new high-level jobs; } \\
\text { enhanced safety at work }\end{array}$ \\
\hline
\end{tabular}

3D Printing;

Authentication and Fraud

Detection; Cyber-Physical Systems; Simulation; Robotics; Virtual

Manufacturing

\begin{tabular}{|c|c|c|c|}
\hline $\begin{array}{l}\text { Bag et al. } \\
(2020)\end{array}$ & $\begin{array}{l}\text { South } \\
\text { Africa }\end{array}$ & Survey & $\begin{array}{l}\text { Examined the link } \\
\text { between Industry } 4.0 \\
\text { and logistics } \\
\text { operations, green } \\
\text { manufacturing, re- } \\
\text { manufacturing, and } \\
\text { business process } \\
\text { optimization }\end{array}$ \\
\hline
\end{tabular}

IoT, CPS, Cloud

Computing, Sensor-based networks; GIS

Industry 4.0 adoption was found to have a positive

impact on green manufacturing and remanufacturing capabilities and business logistics sustainability (mediated through logistics operations).

Environmental Implications: Improved green image; green design; reduction in solid waste management and waste water treatment

Economic Implications: Cost savings; improved visibility resilience, process optimization; resource utilization; improved capabilities and traceability

Social Implications: Facilitate training and skills development

\begin{tabular}{|c|c|c|c|c|}
\hline $\begin{array}{l}\text { Ejsmont et } \\
\text { al. (2020) }\end{array}$ & Generic & $\begin{array}{l}\text { Systematic } \\
\text { literature } \\
\text { review and } \\
\text { bibliometric } \\
\text { analysis }\end{array}$ & $\begin{array}{l}\text { Conceptualization of } \\
\text { the link between } \\
\text { Industry } 4.0 \text { and TBL } \\
\text { sustainability }\end{array}$ & $\begin{array}{l}\text { Big Data Analytics; CPS; } \\
\text { cloud computing; IoT; } \\
\text { Industrial IoT; Cyber- } \\
\text { Physical Production } \\
\text { Systems (CPPS), Digital } \\
\text { Twin }\end{array}$ \\
\hline
\end{tabular}

Industry 4.0 technologies lead to sustainable manufacturing; sustainable energy consumption; sustainable and green supply chain management; smart factory; circular economy

Environmental Implications: Positive implications include an increase in energy efficiency and decrease in manufacturing scrap waste, while negative implications include an increase in electro-waste, energy consumption, etc.

Economic Implications: Positive implications include improved resource efficiency; savings through more accurate planning, shorter lead times, and waste management costs; while negative implications include the high upfront cost of implementation, uncertain return on investments, etc.

Social Implications: Positive implications include an increase in safety, more comfortable working environment, while negative implications include unemployment threats, privacy issues, etc.

\begin{tabular}{|c|c|c|c|c|c|}
\hline $\begin{array}{l}\text { Furstenau et } \\
\text { al. }(2020)\end{array}$ & Generic & $\begin{array}{l}\text { Systematic } \\
\text { literature } \\
\text { review and } \\
\text { bibliometric } \\
\text { analysis }\end{array}$ & $\begin{array}{l}\text { Conceptualization of } \\
\text { the link between } \\
\text { Industry } 4.0 \text { and TBL } \\
\text { sustainability }\end{array}$ & $\begin{array}{l}\text { CPS, Big Data Analytics; } \\
\text { Advanced Manufacturing; } \\
\text { Additive Manufacturing; } \\
\text { 3D Printing; AI, VR, AR, } \\
\text { IoT; Industrial IoT; } \\
\text { Electric Vehicles; }\end{array}$ & $\begin{array}{l}\text { Industry } 4.0 \text { technologies lead to sustainable } \\
\text { manufacturing; sustainable operations, recycling, } \\
\text { life-cycle assessment; circular economy } \\
\text { Environmental Implications: Positive and } \\
\text { negative implications on the environment such as } \\
\text { resource and energy consumption }\end{array}$ \\
\hline
\end{tabular}




\begin{tabular}{|c|c|c|c|c|c|}
\hline Study & Country & Methodology & Primary Focus & $\begin{array}{c}\text { Construction } 4.0 \\
\text { technologies considered }\end{array}$ & $\begin{array}{c}\text { Key findings } \\
\text { (Implications on sustainability) }\end{array}$ \\
\hline & & & & $\begin{array}{l}\text { Robotics; Digital Twins; } \\
\text { Smart Grid; }\end{array}$ & $\begin{array}{l}\text { Economic Implications: Positive and negative } \\
\text { implication on productivity (Productivity } \\
\text { Paradox) } \\
\text { Social Implications: Positive implications include } \\
\text { training and upskilling of workers, creation of new } \\
\text { jobs; while negative implications include loss of } \\
\text { low-skill jobs leading to unemployment and } \\
\text { shortage of skilled employees }\end{array}$ \\
\hline \multirow[t]{3}{*}{$\begin{array}{l}\text { Ghobakhloo } \\
(2020)\end{array}$} & \multirow[t]{3}{*}{ Iran } & \multirow[t]{3}{*}{ Focus groups } & \multirow{3}{*}{$\begin{array}{l}\text { Examined the } \\
\text { opportunities of } \\
\text { Industry } 4.0 \text { for } \\
\text { sustainability }\end{array}$} & \multirow[t]{3}{*}{$\begin{array}{l}\text { Industry } 4.0 \text { technologies } \\
\text { in general }\end{array}$} & $\begin{array}{l}\text { Environmental Implications: Carbon emission } \\
\text { reduction; reduction in energy and resource } \\
\text { consumption }\end{array}$ \\
\hline & & & & & $\begin{array}{l}\text { Economic Implications: Improved corporate } \\
\text { profitability; reduction in manufacturing costs; } \\
\text { agility and flexibility; production efficiency and } \\
\text { productivity }\end{array}$ \\
\hline & & & & & $\begin{array}{l}\text { Social Implications: } \\
\text { development, enhanced } \\
\text { management; job creation }\end{array}$ \\
\hline \multirow{2}{*}{$\begin{array}{l}\text { Margherita } \\
\text { and } \\
\text { Braccini } \\
(2020)\end{array}$} & \multirow[t]{2}{*}{ Generic } & \multirow[t]{2}{*}{$\begin{array}{l}\text { Systematic } \\
\text { literature } \\
\text { review }\end{array}$} & \multirow{2}{*}{$\begin{array}{l}\text { Conceptualization of } \\
\text { the link between } \\
\text { Industry } 4.0 \text { and TBL } \\
\text { sustainability }\end{array}$} & \multirow[t]{2}{*}{$\begin{array}{l}\text { 3D Printing; IoT; Robotics; } \\
\text { CPS; Big Data; VR; } \\
\text { Hologram }\end{array}$} & $\begin{array}{l}\text { Environmental Implications: Reduction in use of } \\
\text { natural resources, carbon emissions, and energy } \\
\text { usage }\end{array}$ \\
\hline & & & & & $\begin{array}{l}\text { Economic Implications: Improvement in } \\
\text { productivity production efficiency, quality, supply } \\
\text { chain management, inventory management, new } \\
\text { value-added services } \\
\text { Social Implications: Improved employee morale, } \\
\text { safer work environment, less intense workload, } \\
\text { job-enrichment }\end{array}$ \\
\hline $\begin{array}{l}\text { Bag et al. } \\
(2021)\end{array}$ & $\begin{array}{l}\text { South } \\
\text { Africa }\end{array}$ & $\begin{array}{l}\text { Literature } \\
\text { review and } \\
\text { survey }\end{array}$ & $\begin{array}{l}\text { Examined the link } \\
\text { between Industry } 4.0 \\
\text { and sustainable } \\
\text { production and } \\
\text { circular economy }\end{array}$ & $\begin{array}{l}\text { Additive and Advanced } \\
\text { Manufacturing; AR; VR; } \\
\text { Robotics; Big Data } \\
\text { Analytics; Blockchain; } \\
\text { Cloud Computing; Cyber- } \\
\text { Security; CPS; Industrial } \\
\text { IoT; Digital Twins; } \\
\text { Simulation and Modeling }\end{array}$ & $\begin{array}{l}\text { Environmental Implications: Industry } 4.0 \\
\text { adoption was found to have a positive impact on } \\
\text { sustainable manufacturing and an indirect impact } \\
\text { on circular economy mediated through sustainable } \\
\text { manufacturing. }\end{array}$ \\
\hline
\end{tabular}

remanufacturing, operations and maintenance, and end of life management (Bag et al., 2020; Ejsmont et al., 2020; Furstenau et al., 2020; Beltrami et al., 2021). Some studies have even explored the relevance of Industry 4.0 for broader sustainability goals, such as green/sustainable supply chain management, closed-loop supply chain, and circular economy (Bag et al., 2021; Ejsmont et al., 2020; Furstenau et al., 2020; Beltrami et al., 2021). Also, several studies in the generic literature have started examining the positive and negative implications of Industry 4.0 on TBL of sustainability (e.g., Ejsmont et al., 2020; Furstenau et al., 2020; Beltrami et al., 2021). Further, studies in the generic literature provided the conceptual base for the thematic classification of Industry 4.0 technologies into managerially relevant categories such as digitalization
(Beltrami et al., 2020; Ejsmont et al., 2020), automation (Beltrami et al., 2021; Ejsmont et al., 2020; Bag et al., 2020), advanced manufacturing (Ghobakhloo, 2020), integration and collaboration (Kamble et al., 2018; Ghobakhloo et al., 2020; Beltrami et al., 2021), and intelligent environment (Kamble et al., 2018; Beltrami et al., 2021; Bag et al., 2020). Finally, a few studies have proposed generic frameworks to conceptualize the various relationships between Industry 4.0 and Sustainability. For instance, Beltrami et al. (2021) proposed a framework for researchers and practitioners to examine the direct impact of Industry 4.0 on TBL of sustainability and mediated impact through practices such as sustainable design, procurement, and manufacturing. Similarly, Ejsmont et al. (2020) proposed a Sustainable Industry 4.0 reference framework to conceptualize 
the impact of Industry 4.0 on sustainability practices such as sustainable manufacturing, TBL of sustainability, circular economy, and sustainable supply chains. Bag et al. (2020) proposed a research framework linking Industry 4.0 and remanufacturing and green manufacturing capabilities mediated through instrumented, interconnected, and intelligent logistics. Kamble et al. (2018) proposed a framework interconnecting Industry 4.0 and TBL of sustainability outcomes mediated through process integration (humanmachine collaboration and equipment integration). However, except for Bag et al. (2020), none of these frameworks are empirically tested and validated. Although these generic frameworks are by no means comprehensive, they provided a good theoretical background on the meaningful relationships that need to be assessed for our proposed Construction 4.0 sustainability framework. According to Carter and Easton (2011), combining existing frameworks into a comprehensive framework allows investigation of multiple theoretical perspectives simultaneously and helps to define the field's boundaries more rigorously.

\section{Development of the Construction 4.0 Sustainability Framework}

The systematic review of Construction 4.0 combined with the generic review provided the insights necessary for developing the Construction 4.0 sustainability framework.

\section{1) Components of the framework}

The central task of developing any technology framework is carefully identifying the key technologies for inclusion (You and Feng, 2020; Munoz-La Rivera et al., 2021). As seen in Table I, the systematic review enabled us to understand the key Construction 4.0 technologies disrupting the sector. In the next stage, through careful syntheses of studies in Table I and Table II, we have grouped these Construction 4.0 technologies into four dimensions: digitalization, automation and advancement manufacturing, integration and collaboration, and intelligent environment. This simplified conceptualization of Construction 4.0 is critical for the progress of the field, given that the scientific contours of Construction 4.0 are not clearly defined. These dimensions are discussed below.

Digitalization - Digitalization, or converting the physical ecosystem to a digital ecosystem and then managing it virtually, is the foundation of Construction 4.0 (Akazi et al., 2020; Mantha et al., 2021). The aim is to digitize and centrally store the information captured through the Internet of Things (IoT) and other devices across the different life cycle phases of construction, starting from the project inception to the end of life, including the commissioning, operation, and maintenance phases to facilitate real-time monitoring and to undertake advance analytics to identify patterns for improvement. Smart digital technologies such as the IoT, big data analytics, cloud computing, virtual and augmented reality, blockchain, and 3D laser scanning and photogrammetry enable a new phase of digitalization of the sector. Also, construction digitization was adjudged as a catalyst that would facilitate the holistic application of other technologies such as BIM, artificial intelligence, machine learning (Lekan et al., 2020), and holography.

Automation and Advanced Manufacturing - It was evident from the literature review that construction process automation is mainly driven by or facilitated by advancement in robotics, 3D printing, autonomous vehicles and machinery, prefabrication and modularization, and blockchain technology (de Soto et al., 2019; Akyazi et al., 2020). For instance, drones can be deployed for remote inspection and for taking aerial photographs to obtain information from the site, thus monitoring construction progress (Muñoz $\square$ La Rivera et al., 2021). Similarly, advanced manufacturing such as additive and $3 \mathrm{D}$ printing enables the manufacturing of buildings layer-bylayer by an automated machine, based on digital 3D models (Akyazi et al., 2020). Further, construction has the potential to benefit from cloud manufacturing, a networked manufacturing mode that utilizes online manufacturing resources to provide a spectrum of on-demand manufacturing services according to users' needs (Singh et al., 2021).

Integration and Collaboration - Identification of Construction 4.0 technologies that integrate different technologies and facilitate collaboration among stakeholders is essential. Lack of early engagement and collaboration of various stakeholders is identified as a key challenge facing the construction sector (Balasubramanian and Shukla, 2017a; $2017 \mathrm{~b}$ ), and integration of different technologies can provide unique benefits that are not available with the use of individual technologies on a standalone basis (You and Feng, 2020).

$\mathrm{BIM}$ is a collaborative working methodology involving key stakeholders (developers, designers, contractors/subcontractors, and suppliers) to design, construct, and operate construction projects (Muñoz $\square$ La Rivera et al., 2021). BIM provides all stakeholders with a digital representation of a building's characteristics throughout its life cycle. Similarly, BIM-Cloud is an integrated technology that allows project teams to work together in different locations to monitor and control the project progress in real-time (Ibrahim et al., 2019). Cyber-Physical Systems are mechanisms that establish bidirectional integration between physical and virtual components. Similarly, blockchain is an "immutable distributed ledger" that records all validated discrete and encrypted digital data events and transactions that are executed or shared among participants in a network, thereby increasing greater accountability, transparency, trust, and collaboration among stakeholders. The integration of blockchain and BIM ensures change tracking and data ownership (Calvetti et al., 2020). Similarly, digital twins provide a realistic digital representation of assets, processes, or systems that integrates the physical and virtual worlds. It has three main elements: a physical artifact, a digital counterpart, and the connection that binds the two together. The connection is the exchange of data, information, and knowledge between the physical and virtual counterparts (Sacks et al., 2020). Finally, advanced Geographical Information Systems (GIS) provide real-time information to automatically track and localize material throughout the construction supply chain, thereby improving material and information flow (Dallasega, 2018). 
Intelligent Environment - Construction 4.0 technologies have the potential to take the sector to an intelligent construction era. Advances in machine learning and artificial intelligence enable the sector to track, monitor and respond to situations like humans do and learn from each other's experiences. Further, an intelligent environment can be created by combining various Construction 4.0 technologies. A smart construction site combines various technologies such as drones, IoTs, automated machines that are able to function with little or no human intervention and act according to the environment. For instance, a robot on a construction site should be able to stop construction activities itself after recognizing that the weather is about to change (Osunsanmi et al., 2020). Machine learning enables systems to evolve as if they were learning (You and Feng, 2020). Advanced simulation techniques utilize real-time data to simulate the execution of the remaining tasks based on the current working status (You and Feng, 2020). Similarly, the discrete event simulation (DES) method could be used to verify project feasibility, progress, potential conflicts, productivity dynamics, and resource utilization, while alternative changes to construction planning can be evaluated with agent-based simulations (You and Feng, 2020). Finally, cyber-security is critical for countering cyberattacks and systemic breaches, such as data thefts in construction projects that use digital infrastructure and intelligent environments (Mantha et al., 2021).

2) Relationship between Construction 4.0 and environmental, social, and economic sustainability

The final component of the framework is to examine the impact of Construction 4.0 on TBL of sustainability. While the common expectation is that Construction 4.0 supports the broader sustainable development goals, the technology could potentially exacerbate some of the issues facing the sector. Our generic review (Table II) shows that Industry 4.0 has both positive and negative impacts on all three dimensions of sustainability. The limited evidence from Table I also supports that Construction 4.0 has both positive and negative impacts on sustainability. For example, 3D printing could significantly reduce material usage and onsite waste. On the other hand, machine learning and artificial intelligence algorithms consume significant energy, negatively impacting the environment (du Plessis and Sherratt, 2020).

\section{3) The proposed sustainability framework for Construction} 4.0

Fig. 3 shows the proposed Construction 4.0 sustainability framework. Central to the framework are the various interconnected Construction 4.0 technologies. These technologies are categorized into four meaningful and managerially relevant dimensions. Finally, the framework captures the multifaceted impact of Construction 4.0 on environmental, social, and environmental sustainability dimensions. We expect practitioners and policymakers to find this framework a valuable tool for assessing their current and future readiness of the sector in Construction 4.0.

\section{APPLICATION OF THE FRAMEWORK IN THE CONSTRUCTION} SECTOR

\section{A. Research setting}

Having developed the Construction 4.0 sustainability framework, the next stage was to test its applicability in a realworld setting. While it could be tested anywhere, choosing a setting where the construction intensity is high but at the same time making significant efforts towards TBL of sustainability and implementation of Industry 4.0 technologies could be more practically relevant. The UAE was carefully chosen as the case country for the investigation due to the following reasons.

The UAE construction sector has experienced an unprecedented construction boom, growing at more than $9 \%$ per annum in the last few decades (Balasubramanian and Shukla, 2017a). Some of the largest construction projects in the world, including the tallest structure (Burj Khalifa), the tallest hotel (JW Marriott Marquis), and the largest mall (Dubai Mall), have taken place there recently (Balasubramanian and Shukla, 2017b). Unfortunately, this unprecedented growth has placed a substantial environmental burden on the country (around 75\% of all the solid waste generated in UAE is from construction, including carbon emissions), and is the main contributor to UAE's status as one of the most polluting countries in the world in terms of carbon emissions. From a social standpoint, the UAE construction sector accounted for the highest number of employed persons, especially blue-collar workers in the UAE, at around 1.64 million (Statista, 2020) and constituted 33.9\% of the total private-sector workforce (UAE MOE, 2019). From the economic standpoint, construction is a critical sector for the country's diversification from an oil-based economy. Of the non-oil-based sectors, construction is one of the top contributors, with a contribution of $8.5 \%$ to UAE's overall GDP. Therefore, the construction sector needs to keep pace with the UAE's ambition to foster an ecosystem of modern, productive, and technology-driven construction. The UAE is among the few countries globally to have adopted a national strategy for the Fourth Industrial Revolution (UAE MCAF, 2017). The UAE aims to become a global hub and the world's first open lab for experimenting and adopting the Fourth Industrial Revolution's technologies. The UAE's strategic vision defines a path to establish the country as the most competitive nation in the world by its 100th birthday (UAE Centennial 2071, 2021). Also, UAE has taken several sustainability initiatives to become one of the most sustainable countries. Sustainable development is at the heart of the UAE's vision and the country is fully committed to its 2030 national agenda towards achieving the United Nations sustainable development goals (NCSDG, 2018). Thus, the UAE provides an ideal setting to assess opportunities and challenges associated with Industry 4.0 in the construction sector in achieving environmental, economic, and social sustainability.

\section{B. Case study methodology}

The case study methodology was deemed to be the most appropriate for examining a contemporary topic in a real-world situation (Yin, 2009). Although the study adopted was a single 


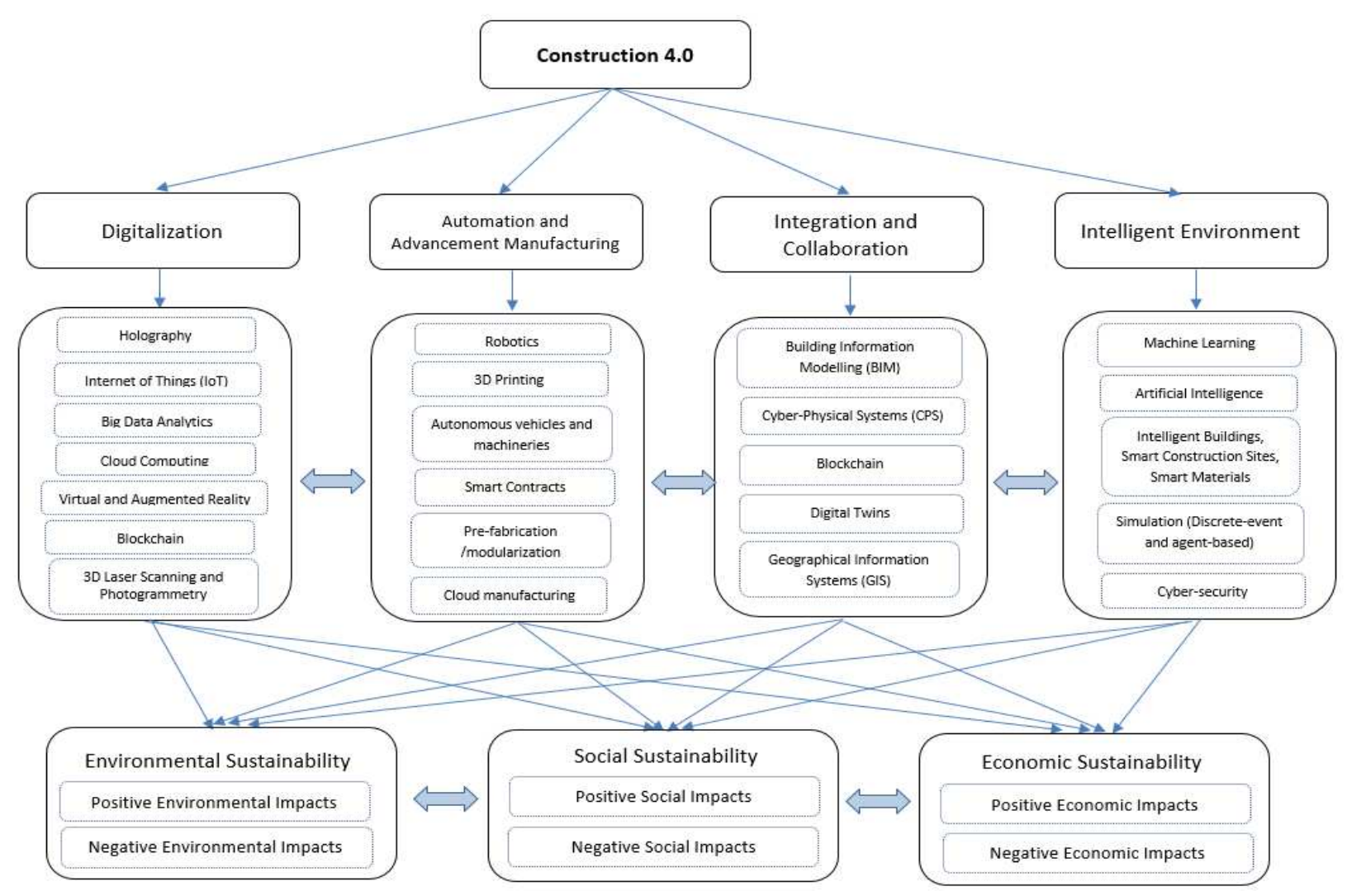

Fig. 3. Systematic Review of Construction 4.0

case design (UAE construction sector), it featured an embedded case design with multiple units of analysis (Yin, 2009). In terms of methods, a pragmatic, sequential multi-methodology approach combining both quantitative and qualitative methods and utilizing both primary and secondary data was adopted for the case study. This enabled the authors to develop a comprehensive understanding of various strands of the framework and, in the process, answer the research questions. The use of a pragmatic approach was justified, given that practical, realistic solutions are needed to inform practice, especially considering the newness of the topic. The primary research was conducted using both interviews and surveys.

\section{1) Interviews}

The interviews (in line with our research questions) aimed to understand the respondents' experience and perception of Industry 4.0 technologies, their opportunities and challenges, and their positive and negative impact on the UAE construction sector's social, environmental, and economic sustainability aspects. A semi-structured interview approach was preferred because the scope of the interviews revolved around these themes. The detailed interview protocol used in this study is given in Appendix 1. Purposive sampling, a non-probability sampling technique, was used to recruit the participants (Lavrakas, 2008). This is because, to get quality and in-depth information on the research questions, it was not possible to recruit any construction industry professional at random for interviewing; instead, it was necessary to ensure the designation and experience of the interviewees were relevant to the questions that were posed. Also, purposive sampling ensured that interview participants represented cross-sections of the construction sector stakeholders (i.e., developers, architects/consultants, contractors/sub-contractors, and material suppliers), as well as academics and government officials. In terms of the strategy used to recruit participants, more than 50 potential participants who met the qualifying criteria were contacted by email with a brief description of the intended study. A total of 12 semi-structured interviews were conducted with senior professionals (who expressed their willingness to be interviewed), most of whom had more than 10-15 years of experience in the construction sector. The sample size falls within the recommended minimum 5-25 sample size for semi-structured interviews (Saunders et al., 2016). Previous studies have shown that semi-structured interviews with a minimum of 8-12 participants can provide meaningful insights and sufficient generalizability (DeJonckheere and Vaughn, 2019). The depth of knowledge and experience of interviewees ensured quality answers were received to the questions posed, safeguarding the reliability of the data (Bryman, 2016). The purposive cross-section sampling ensured the participants are representative of the constructive sector (Saunders et al., 2016).

The demographic profile of the interviewees is provided in Table III. Due to COVID-19 constraints, most of the interviews were conducted virtually. Each interview lasted approximately 45-60 min, with a focus on "how," "what," and "why. Most were digitally recorded, and where this was not possible, detailed notes were taken and cross-checked with the 
respondents for accuracy. Thematic analysis (guided by the framework) was used to analyze the interview data. Information related to the Industry 4.0 technologies was categorized under the four categories: Digitalization; Automation and Advancement Manufacturing; Integration and Collaboration; and Intelligent Environment. Codes were assigned to an individual Industry 4.0 technology within these sub-categories. For example, big data was assigned a specific code within category 1 (Digitalization). Similarly, the social, environmental, and economic sustainability implications of Industry 4.0 were coded and categorized under six categories: positive environmental; negative environmental; positive social; negative social; positive economic; and negative economic implications. Further, to improve the reliability of data analysis, the coding was conducted independently by two authors.

TABLE III

KEY INFORMANTS FOR INTERVIEWS

\begin{tabular}{clll}
\multicolumn{4}{c}{ KEY INFORMANTS FOR INTER VIEWS } \\
\hline S. No & Interviewee & $\begin{array}{l}\text { Experience } \\
\text { (in years) }\end{array}$ & Stakeholder \\
\hline 1 & Environmental Manager & 12 & Developer \\
2 & Manager - Corporate Social & $25+$ & Developer \\
& Responsibility & & Main Contractor \\
3 & Senior Manager - Head of Projects & 9 & Architect/Consultant \\
4 & Chief Architect & 18 & Sub-Contractor \\
5 & Project Manager & 12 & Architect/Consultant \\
6 & Senior Consultant & 20 & Main Contractor \\
7 & Health and Safety Officer & 6 & Supplier of Steel (Manufacturer) \\
8 & Production Head & 15 & Supplier of Aluminum (Manufacturer) \\
9 & Procurement Manager & 25 & Dubai Municipality \\
10 & Senior Manager & 10 & Government Entity \\
11 & Trainer/Researcher & 12 & University \\
12 & Professor (Build Environment) & $30+$ &
\end{tabular}

\section{2) Survey}

In the next stage, a short survey was conducted to assess the current and future state (in the next five years) of the adoption of Construction 4.0 in the UAE construction sector. Only key Construction 4.0 technologies identified during the interviews were included in the survey. Emergent Construction 4.0 technologies in which the interviewees showed limited knowledge and awareness (e.g., holography, cloudmanufacturing, digital twins) were excluded from the survey. A sample question to capture the present state of adoption of Construction 4.0 technologies is "Please rate the extent of adoption of 'blockchain' in the UAE construction sector. Regarding the survey scale to capture the present state, a Likert scale (1-5) ranging from "not considered at all (1)" to "highly considered (5)" were used. Similarly, a sample question to capture the future state of adoption of Construction 4.0 technologies is "Please rate the extent to which 'blockchain' will be adopted over the next five years." The corresponding Likert scale (1-5) ranged from "not at all (1)" to "very high extent (5)". The survey instrument used is provided in Appendix 2.

The survey was administrated via Qualtrics, a leading online survey platform, for a period of two months (January - February 2021). In terms of sampling, a random sampling approach was used in which the survey was sent to a random sample of 1000 respondents from a database of $3000+$ industry professionals
(Zawya database, which we paid to access, and one of the authors' personal LinkedIn contacts of construction sector professionals). Overall, a total of 121 useable responses were obtained, an effective response rate of $12.1 \%$.

3) Secondary Data

In the next phase, secondary data from reliable sources relevant to Industry 4.0 adoption in the UAE construction sector and elsewhere were assembled, coded, and analyzed to complement the primary research findings. To ensure reliability and rigor in the secondary data, we considered only reports from leading consulting firms, governments, and global organizations.

\section{FindingS AND DisCUSSIONS}

The findings are organized and discussed in line with the research questions (RQ) stated initially.

RQ 1 - What is the current and future state of Construction 4.0 technologies, and how are they disrupting the sector?

RQ 2 - What are the positive and negative implications of these Construction 4.0 technologies for the sector's environmental, economic, and social sustainability?

\section{A. Current and Future Prospects of Construction 4.0 in the $U A E$}

In this section, the survey and interview findings are discussed in relation to the current and future prospects of Industry 4.0 in the UAE construction sector. Table IV summarizes the survey findings. A paired t-test was used to check for statistical differences in the current and future state of Construction 4.0 technologies. As seen in the table, the results show that there is a significant difference $(p<0.001)$ across all technologies, with survey respondents perceiving that these technologies will be widely adopted in the future (in the next five years).

TABLE IV

CURRENT AND FUTURE STATE OF INDUSTRY 4.0 IN CONSTRUCTION

\begin{tabular}{lccc}
\hline & $\begin{array}{c}\text { Current State } \\
(\mathbf{1}-5)\end{array}$ & $\begin{array}{c}\text { Future State } \\
\mathbf{( 1 - 5 )}\end{array}$ & Difference \\
Industry 4.0 Technologies & $\mathbf{3 . 2 4}$ & $\mathbf{4 . 2 1}$ & $\mathbf{0 . 9 7 ^ { * * * }}$ \\
\hline Digitalization & 3.64 & 4.59 & $0.95^{* * *}$ \\
Internet of Things (loTs) & 3.39 & 4.23 & $0.84^{* * *}$ \\
Big Data Analytics & 2.96 & 3.71 & $0.75^{* * *}$ \\
Cloud Computing & 3.50 & 4.52 & $1.02^{* * * *}$ \\
Virtual and Augmented Reality & 3.12 & 4.32 & $1.20^{* * * *}$ \\
Blockchain & 2.80 & 3.86 & $1.06^{* * *}$ \\
3D Laser Scanning and Photogrammetry & & & \\
& 3.33 & 4.33 & $\mathbf{1 . 0 0 * * *}$ \\
Automation and Advancement Manufacturing & 3.74 & 4.62 & $0.88^{* * *}$ \\
Automation using Robotics (Onsite) & 3.92 & 4.66 & $0.74^{* * *}$ \\
Automation using Robotics (Off-site) & 3.11 & 4.40 & $1.29^{* * * *}$ \\
3D Printing (Additive Manufacturing) & 3.56 & 4.65 & $1.09^{* * *}$ \\
Drones & 2.68 & 3.54 & $0.86^{* * *}$ \\
Autonomous onsite vehicles & 2.99 & 4.12 & $1.13^{* * *}$ \\
Smart Contracts & & & \\
& 3.18 & 4.14 & $\mathbf{0 . 9 6}$ \\
Integration and Collaboration & 3.99 & 4.75 & $0.76^{* * *}$ \\
Building Information Modeling & 2.44 & 3.35 & $0.91^{* * * *}$ \\
Cyber-Physical Systems (CPS) & 3.12 & 4.32 & $1.20^{* * *}$ \\
Blockchain* & & & \\
Intelligent Environment & $\mathbf{2 . 9 2}$ & $\mathbf{3 . 8 1}$ & $\mathbf{0 . 8 9 * * *}$ \\
Machine Learning & 2.87 & 3.79 & $0.92^{* * *}$ \\
Artificial Intelligence & 2.85 & 3.68 & $0.83^{* * *}$ \\
Smart Materials (e.g., Self-healing, Self-Cleaning materials) & 2.47 & 3.27 & $0.80^{* * * *}$ \\
Smart Construction Sites & 3.50 & 4.51 & $1.01^{* * *}$ \\
\hline
\end{tabular}

*Blockchain is repeated and its comes under both digitalization and integration and collaboration categories; $* * *$ Significant at $\mathrm{p}<0.001$ 


\section{1) Digitalization}

As seen in Table IV, the current state of digitalization in the UAE construction sector is 3.24 out of 5.00. However, in the next five years, respondents believe this will significantly increase to 4.21. Most interviewees said they expect an acceleration in the digitalization drive, largely due to the COVID-19 pandemic. The COVID-19 pandemic has forced the sector to find safer and smarter ways to build. In the words of one interviewee: "Construction 4.0 technologies have allowed us to continue working in a virtual and digital environment despite being unable to meet in person". At the individual level, IoT emerged as the most implemented technology, with a mean score of 3.64, and is also the technology that is forecasted to be the most implemented in the future (4.59). This is in line with the findings of Forcael et al. (2020), who found IoT to be the most discussed Construction 4.0 technology. The promising outlook was reflected during the interviews. According to the interviewees, most contracting firms are using RFID tags to have real-time visibility of their materials and equipment. A few of the respondents (from the main contractor) mentioned that they continuously track their materials and equipment from warehouse to construction site. This allows them to efficiently plan their deliveries to the site, as well as to share equipment and machinery across multiple project sites and to reduce mishandling and theft. This echoes the findings in the literature that highlighted the application of RFID tags to automatically identify, geolocate and track materials and machinery for their control at construction sites (Muñoz-La Rivera et al., 2021). In addition, a respondent from the main contractor highlighted the onsite use of smart sensors to continuously monitor dust, noise, vibration level (such as during piling), motion detection to capture unauthorized access to project sites, hazardous fumes, among other technologies. The system will send automated notifications (as email and SMS) if the values are greater than the threshold levels. Previous studies have reported the use of sensors in construction to monitor the structural health of buildings and infrastructures, to check the correct operation of machinery, workers, equipment, systems, thermal comfort, among other applications (Akyazi et al., 2020; Muñoz-La Rivera et al., 2021). In addition, interviewees highlighted the growing importance of smart wearables for construction workers to enhance worker safety, with uses including monitoring their vital signs and detecting if workers are tired or overworked. In the words of the respondent: "Some of the technologies such as smartwatches are already there and not very expensive, and we can roll them out fast." Recent studies in construction have also reported the use of wearables devices with sensors, cameras, and mobile locators to collect the realtime status of workers on site (You and Feng, 2020; Muñoz-La Rivera et al., 2021).

Virtual and augmented reality emerged as the second-most implemented technology (3.50) at present and in the future as well (4.52). Providing an immersive virtual experience of the construction project for stakeholders and clients is fast becoming the norm in the construction sector. Similarly, respondents (from contracting/sub-contracting firms) highlighted that the COVID-19 social distancing constraints mean fewer employees at construction sites. This has forced them to use augmented reality to solve onsite issues remotely by experts without being physically present. This is facilitated by the smart camera attached to the helmet of the onsite workers. Most respondents also highlighted the increase in the use of virtual and augmented reality solutions for training programs, project reviews, and planning meetings. Previous studies have reported the use of virtual and augmented reality in architectural design, maintenance and repair work at construction sites, quality and defect management, employee training, and safety management (Ahmed, 2018; Forcael et al., 2020).

Big data analytics emerged as the third most implemented technology in this category (3.39). The future prospects of big data analytics also look promising, with a mean score of 4.23. One of the interviewees (a project manager) mentioned that they are looking to hire a data scientist (for the first time) to join their project team, echoing the growing importance of data analytics in the construction sector. However, a few of the interviewees admitted that they are not fully utilizing the data, especially those captured by their IoT networks, and would like to see more advanced predictive and prescriptive analytics in the future. This lack of data utilization is a concern, given that big data analytics can identify valuable patterns, trends, or correlations for the optimization of the processes of design, construction, and building maintenance (Muñoz-La Rivera et al., 2021).

Blockchain emerged as the fourth most implemented technology in the category (3.12). However, among other technologies in this category, blockchain is expected to get the biggest push in the future (4.32). This is echoed in the interviews. According to respondents, this is because of the UAE government's support of blockchain technology, particularly its Blockchain Strategy 2021 (UAE, 2020). Many public sector entities in the UAE are already adopting blockchain solutions (World Economic Forum, 2020). Some of the interviewees from the government entity highlighted the use of blockchain by the land department to record all sales and lease transactions in the secure blockchain ledger, thereby enhancing transparency, as these transactions are immutable. This is important given the delay, ambiguity, and legal concerns related to the construction contacts. It also supports the Dubai government's "Paperless Strategy," which aims to build an integrated, paper-free government framework by the year 2021 and, in the process, eliminate more than a billion pieces of paper used for government transactions (Balasubramanian et al., 2021). Previous studies have also advocated using blockchain in construction to improve safety and efficiency by providing automatic verification of design codes and regulations, security and greater ease in tracking change control and permit management, and developing smart contracts (Muñoz-La Rivera et al., 2021). The integration of blockchain and BIM ensures change tracking and data ownership. It could make construction industry contracts more trustful and less prone to claims or change orders (Calvetti et al., 2020a).

Surprisingly, cloud computing emerged as the second-least implemented technology (2.96) in this category and the least 
likely technology to be implemented in the future (3.71). It was evident from the interviews that construction firms in the UAE have started using the cloud for data storage and sharing across different stakeholders. This is because of the scalability of the cloud to store heavy file sizes of high-resolution images, 3D simulation models, animations, etc. The central management of files in the cloud environment allows better manageability and real-time anywhere access. Further, the use of cloud systems reduces infrastructure complexity and also reduces cost. However, respondents were either not aware or had a limited understanding of distributed computing, sharing of information technology capabilities, or delivering applications as a service. The fact that cloud computing means different things to different people may explain the relatively lower score in the survey. Low adoption of cloud computing is a concern, given that it can reduce the total cost of ownership of construction projects via services modes such as Infrastructure-as-a-Service (IaaS), which provides users with virtual computers and servers; Platform-as-a-Service (PaaS), which provides users with services such as operating systems, databases, and programming languages; and Software-as-a-Service (SaaS), which allows users to access their applications through the internet (You and Feng, 2020).

Although 3D laser scanning and photogrammetry emerged as the least implemented technology in this category (2.80), respondents indicated that it is likely to get a significant push in the future (3.86). This is echoed in the interviews. Most respondents agreed on the potential of this technology. A few interviewees highlighted that they have already started using laser scanning in their projects to develop 3D models to determine project progress and compare against the original 3D design. According to them, the use of laser scanning and photogrammetry, techniques to obtain geometric properties of objects and their spatial locations, is likely to increase due to COVID-19, as it will reduce the number of onsite workers and project managers. This is because laser scanning and photogrammetry enable remote inspection and monitoring (Muñoz-La Rivera et al., 2021). Other laser scanning applications evident from the literature include real-time feedback for quality control (Sacks et al., 2020). For instance, laser scanning can be used to precisely position construction materials as they are placed using a crane, which eliminates costly re-work and variations.

\section{2) Automation and Advancement Manufacturing}

The present state of automation and advanced manufacturing in the UAE construction sector is 3.33 out of 5.00 and has the highest score across the four categories. Moreover, this is expected to increase to 4.33 in the next five years. At the individual technology level, automation using robotics (offsite) emerged as the most implemented technology with a mean score of 3.92 and is also the technology that respondents predict will be the most implemented in the future as well (4.66). This is not surprising, given the significant advancement in robotics in the manufacturing sector. This is echoed in the interviews with respondents from steel and aluminum manufacturing firms. According to them, $80-90 \%$ of the manufacturing process is automated. The other respondents underlined the significant (recent) increase in the modular design in the UAE construction sector as the reason for the rise in the offsite prefabrication of components using robotic technology, as it offers faster production, lower cost, and more efficient assembly of elements compared to in-situ construction. Previous studies have also advocated using off-site construction as it only requires assembly and installation on-site and hence optimizes time, logistics, and quality of finishes. Moreover, it facilitates manufacturing in a controlled environment using rigorous quality-control principles, eliminating exposure to uncertain weather conditions at the building construction site (Muñoz-La Rivera et al., 2021).

According to one of the interviewees (a developer), it is cheaper to use prefabrication in housing development projects involving identical houses or villas. Most components, including ceilings, walls, and balcony and bathroom pods, can be prefabricated offsite using automation. For example, DuBox, a Dubai-based modular construction company, designs and delivers single- or multi-story concrete buildings using modular methodologies. It shifts 85 percent of the construction activities offsite and is the first company in the Middle East and North Africa to apply offsite modular manufacturing methods to concrete construction projects (DuBox, 2020). However, two respondents (one architect and one consultant) cautioned that the growing need for construction projects to be unique (different from others) would become a roadblock for modular construction and offsite prefabrication. Also, respondents were relatively unaware of the cloud manufacturing possibilities for the construction sector.

Onsite use of automation emerged as the second-most implemented technology (3.74) and in the future as well (4.66). According to respondents, most construction sites are using some degree of automation. According to some interviewees (main contractors), they use onsite robotic technology for plastering and panel installation. The use of automation has significantly reduced manual waste and re-works from errors along with effecting a reduction in project completion time. One respondent (a developer) mentioned their use of automated robots for cleaning windows of high-rise buildings compared to manual window washers using ropes. This significantly increases construction worker safety. This echoes the growing calls in the literature to use robotics and automation to reduce the number of lives lost due to fatal accidents at construction sites (Turner et al., 2021). However, respondents did acknowledge that it may not be feasible for small-scale developers and individual building owners, as robotics are pricey to procure and require costly maintenance.

Drones emerged as the third most implemented technology in the category (3.56) and are also expected to get a significant push in the future (4.65). It is also the third most implemented technology across all categories. The interviewees also revealed the growing significance of drones in the UAE construction sector. According to them, drones significantly reduce the time and effort required in the onsite monitoring and physical supervision of construction projects and reporting procedures. Drones fitted with cameras provide significant cost-savings, eliminate safety risks associated with climbing in a high-rise 
building for inspections and reduce the time required to assess the site conditions. Some respondents highlighted the use of drones for aerial transport of lightweight materials and tools during the construction of high-rise buildings. Secondary evidence also supports the growing usage of drones as the drone market in the UAE is currently among the most advanced and developed in the Middle East (Gulfnews, 2017). Evidence in the literature supports the growing use of drones in the construction sector, since they can capture large amounts of data through multiple sensors, such as cameras, laser scanners, and radio-frequency identification (RFID) readers (Craveiro et al., 2019).

3D printing or additive manufacturing emerged as the fourthmost implemented technology in this category (3.11) but emerged as the one to grow the most significantly in the next five years (4.40). The interviews supported this finding. Most respondents were confident that $3 \mathrm{D}$ printing would become the new norm in the post-COVID-19 era as the sector is trying to reduce its dependence on blue-collar workers. They stressed that the UAE is one of the first countries to promote $3 \mathrm{D}$ printing, and most construction firms will use 3D printing, as this is an integral part of the UAE's Industry 4.0 strategy (UAE MCAF, 2017). Dubai Electricity and Water Authority (DEWA) lab is the first 3D-printed laboratory building in the world (DEWA, 2017) and is also collaborating with prestigious research centers and universities worldwide. Unlike modular prefabrication, 3D printing facilitates building complex or unique concrete structures and shapes, and therefore provide significant value-add to contractors. The results mirror the increasing popularity of 3D printing in the literature due to its benefits such as greater quality control, unlimited shapes and geometry configurations, and cost-effectiveness because parts can be created at a fraction of the price compared with standard means of construction due to less waste, use of recycled materials and decrease in transport costs (Newman et al., 2020; Akyazi et al., 2020).

Smart contracts emerged as the second least implemented in this category (2.99). However, similar to drones, this is also expected to grow significantly in the coming years (4.12). Most interviewees were optimistic about the potential of smart contracts, as these will save time (avoid follow-up) in contracting, and their obligations will be fulfilled automatically when the predefined conditions are met. Moreover, the growth of blockchain will increase the adoption of smart contracts, as most of them are powered by blockchain technology. Calvetti et al. (2020) reported the significant application of blockchainpowered smart contracts in the construction sector.

Autonomous construction vehicles emerged as the least implemented technology in this category (2.68), and despite its growth potential, it is likely to remain as the least implemented in the future (3.54). According to a few respondents, autonomous construction vehicles are better suited for road projects and pavements and do not have much potential in building projects. A few respondents had contrasting views as they highlighted the significant progress made in driverless dozers and cranes (which can be operated remotely). In our literature review also, autonomous vehicles have witnessed relatively less interest than other technologies.

3) Integration and Collaboration

The current state of integration and collaboration using Industry 4.0 technologies scored 3.18 out of 5.00. However, it is poised to improve significantly in the next five years (4.14). Of these, building information modeling (BIM) emerged as the most implemented technology, not only in this category, but across all categories (3.99). It is set to grow even further in the coming years (4.75). Evidence from the literature supports the growing use of BIM in the construction sector vis-à-vis other Construction 4.0 technologies (Maskuriy et al., 2019; Osunsanmi et al., 2020; Zabidin et al., 2020). For instance, Mansouri et al. (2020) found BIM as the most implemented technology in the construction sector. Almost all interviewees agreed on the benefit of BIM as a 3D-modeling tool. However, some participants acknowledged that BIM technology is not fully utilized in most cases. According to them, BIM is used mostly at the design stage by architects, and the 3D models are not further utilized by the consultants (for project scheduling), contractors (during the construction phase), and developers (during the operation and maintenance phase). In other words, the additional benefits of BIM, such as scheduling (4D), cost (5D), sustainability (6D), and operations and maintenance (7D), are not utilized. However, interviewees were optimistic that BIM would further enhance collaboration across stakeholders.

Cyber-Physical systems emerged as the least implemented Industry 4.0 technology (2.44). Although it is set to grow in the next five years, it will remain the least popular (3.35). This echoes the bibliometric review findings of Zabidin et al. (2020), who reported cyber-physical systems as the least discussed in the literature. One of the interviewees acknowledged the potential of CPS to integrate different Industry 4.0 technologies. For instance, the data from the IoT network can be integrated with CPS, and blockchain can be used to store these data in a secure cloud environment for advanced data analytics. However, in general, respondents are of the view that the integration of various technologies will take time, especially when it comes to creating an eco-system in which machines will communicate with other machines and make autonomous decisions without human interventions. According to them, the likely benefit of CPS in the near future will be the enhanced human-machine interface. In the words of one of the interviewees: "The role of humans in construction projects will become even more critical in the future, and we must learn to work with these machines just like we are working with our colleagues."

From an integration and collaboration perspective, it was evident from the interviews that contractual collaboration, which is supported and automatized with smart contracts, can decrease the number of claims and disputes significantly, thereby improving stakeholder relationships.

\section{4) Intelligent Environment}

The present state of the intelligent environment in the UAE construction sector is 2.92 out of 5.00 and is the lowest across the four categories. From the current levels, it is expected to improve in the coming years (3.81). Of the various technologies under this category, smart construction sites emerged with the 
highest mean score of 3.50 out of 5.00 at the current level and 4.51 in the future. According to the interviewed contractors, IoTs, sensors, and cameras are critical for developing smart construction sites. The real-time data generated from the sensors can then be used for monitoring and predicting likely events. Application of geofencing emerged a few times during the interviews. According to respondents, the use of GPSenabled geofencing in large development projects enables site managers to set up triggers or alerts for unauthorized entry or exit of equipment, machinery, and workers. One of the interviewees (a subcontractor) mentioned the use of smart mobile applications to track the movement of workers and vehicles within the construction site, including the time spent by employees in a particular location. Similarly, other respondents (main contractors) highlighted their use of speeddetecting radar on the construction site to track the speed of vehicles. The result echoes the growing trend in the literature for smart construction sites (Osunsanmi et al., 2020).

Machine learning (2.87) and artificial intelligence (2.85) emerged as the second and third most implemented technologies in this category, though their scores are relatively much lower compared to other technologies. This is echoed in the interviews. According to interviewees, the UAE construction sector is in the transitioning phase towards Industry 4.0, and machine learning and artificial intelligence require a certain level of maturity. The current technologies are not able to fully substitute human capabilities and abilities such as self-monitoring and self-correction. However, they did acknowledge the fact that even at the current level, machine learning capabilities will enable better prediction and modeling using data from various sources. According to one respondent, advancement in machine learning and AI algorithms in image/photo recognition will add value, as the onsite images captured from drones and other means can be analyzed by machines, leading to a reduction in human bias and error. The algorithms could also determine project progress based on photos. Evidence from the literature suggests greater adoption of machine learning and artificial intelligence in the near future, as they are already advanced in other sectors such as manufacturing. For instance, industrial robots are already being trained to learn how to perform a task (Reinhardt et al., 2020). Artificial intelligence could automate many aspects of the design in the construction sector, based on data from previous works and the study of their behavior over time, Muñoz-La Rivera et al., 2021).

Smart materials emerged as the least implemented technology in this category and second least implemented overall (2.47). This was reflected in the interviews as well. According to respondents, developers and contractors are reluctant to use innovative materials. They highlighted concerns related to the longevity of smart materials. In the words of one interviewee: "some of these materials are only a few years old, and only time will tell how this will perform for the next 20-30 years". They also highlighted the challenge of getting regulatory approval for using these smart materials for projects. However, some of the respondents from contracting firms expressed optimism in adopting smart materials soon.
They highlighted how green materials such a recycled concrete are now widely used in the sector after the initial reluctance. Conmix, a leading ready-mix concrete supplier in the UAE, has signed an agreement with Basilisk, a bacteria-based selfhealing concrete manufacturer based in the Netherlands, to bring this technology to the UAE (Conmix, 2020). One of the respondents (a consultant) highlighted the potential of nanotechnology-based smart materials, such as self-cleaning glass facades for tall buildings, which could significantly reduce the window-cleaning costs of high-rise buildings.

\section{B. Impact of Construction 4.0 on Environmental, Social and Economic Sustainability}

The findings from the interviews and secondary research were used to map the Construction 4.0 impact on the triple bottom lines of sustainability, though some of them are discussed in the above sections. The results revealed both positive and negative impacts on TBL of sustainability. This is in line with previous studies in the literature that reported positive and negative implications of Industry 4.0 on TBL of sustainability (e.g., Ejsmont et al., 2020; Furstenau et al., 2020; Beltrami et al., 2021). Table 5 summarizes the Construction 4.0 impact on environmental, social, and economic sustainability. The key implications are discussed in the following sections.

\section{1) Environmental sustainability implications}

As seen in Table V, Construction 4.0 technologies have both positive and negative environmental implications, though the overall results show that the positive impacts outweigh the negative ones.

Positive Environmental Implications - According to interviewees, one of the advantages of Industry 4.0 technologies on the environmental front is its ability to gather precise, real-time data and then use analytics to garner deep insights on material usage and waste statistics, thereby cutting back on water and energy consumption. This includes sensorbased IoT networks that could facilitate early detection and real-time leakage alerts. Previous studies have reported the application of IoT in the construction sector to gather and share big data streamed from materials, machines, and humans over a network system without human intervention to obtain actionable insights for resource optimization, energy conservation, and emission reductions (Newman et al., 2020; You and Feng, 2020).

Some of the interviewed architects highlighted the significant reduction in $2 \mathrm{D}$ paper-based drawings due to the advancement in 3D modeling and wider acceptance of BIM software, thereby supporting the environment. Similarly, another interviewee (a procurement manager) highlighted their use of AI-based e-tenders for shortlisting and selecting suppliers, significantly reducing the paperwork. He was also optimistic about blockchain-powered smart contracts' potential in further reducing paper works, related travel, and courier services. This echoes the growing relevance of Industry 4.0 technologies in supporting sustainable purchasing (Beltrami et al., 2021). Few other respondents (along similar lines) also mentioned that they are exploring the potential of VR and AR technology to showcase their work to prospective clients, 
TABLE V

MAPPING THE CONSTRUCTION 4.0 IMPACT ON ENVIRONMENTAL, SOCIAL AND ECONOMIC SUSTAINABILITY

\begin{tabular}{|c|c|c|c|c|}
\hline & & Environmental & Social & Economic \\
\hline \multicolumn{5}{|c|}{ Digitalization } \\
\hline & $\begin{array}{l}\text { Holography } \\
\text { Internet of } \\
\text { Things (IoTs) } \\
\text { Big Data } \\
\text { Analytics } \\
\text { Cloud Computing } \\
\text { Virtual and } \\
\text { Augmented } \\
\text { Reality } \\
\text { Blockchain } \\
\text { 3D Laser } \\
\text { Scanning and } \\
\text { Photogrammetry }\end{array}$ & $\begin{array}{ll}\text { Positive impact } \\
\text { Reduced: } \\
\text { - } \quad \begin{array}{l}\text { Resource consumption and } \\
\text { wastages due to enhanced } \\
\text { (real-time) visibility of }\end{array} \\
\text { projects } \\
\text { - } \quad \begin{array}{l}\text { Environmental accidents } \\
\text { due to early detection and }\end{array} \\
\text { predictive analytics } \\
\text { - Usage of paper } \\
\text { Employee transport-related } \\
\text { emissions } \\
\text { Negative impact } \\
\text { Greater: } \\
\text { - } \quad \text { e-waste } \\
\text { Energy usage (from servers } \\
\text { and datacenters) }\end{array}$ & $\begin{array}{l}\text { Positive impact } \\
\text { Improved: } \\
\text { - } \quad \text { Health and safety of workers } \\
\text { - } \quad \text { Transity of life of residents } \\
\text { - Stakeholder relationships } \\
\text { - Greater convenience } \\
\text { programmers) } \\
\text { Freater accountability of all stakeholders } \\
\text { Negative impact } \\
\text { Increased: } \\
\text { Data breaches } \\
\text { Digital surveillance of employees (that } \\
\text { may reduce their morale) } \\
\text { Data privacy issues }\end{array}$ & $\begin{array}{ll}\text { Positive impact } \\
\text { Reduced: } \\
\text { - } \quad \text { Operational costs at project site } \\
\text { - } \quad \text { Project completion time } \\
\text { Theft and misplacement of } \\
\text { * Improves employee productivity } \\
\text { Negative impact } \\
\text { Incurrence of cost related to: } \\
\text { - } \quad \text { Data breaches } \\
\text { - } \quad \text { Cyber security } \\
\text { - } \quad \text { Subscription for cloud services } \\
\text { - } \quad \text { Recruiting and retaining } \\
& \text { technology professionals. }\end{array}$ \\
\hline \multicolumn{5}{|c|}{ Automation and Advancement Manufacturing } \\
\hline & $\begin{array}{l}\text { Robotics } \\
\text { 3D Printing } \\
\text { Drones } \\
\text { Autonomous } \\
\text { vehicles and } \\
\text { machineries } \\
\text { Smart Contracts } \\
\text { Pre-fabrication/ } \\
\text { modularization } \\
\text { Cloud } \\
\text { manufacturing }\end{array}$ & 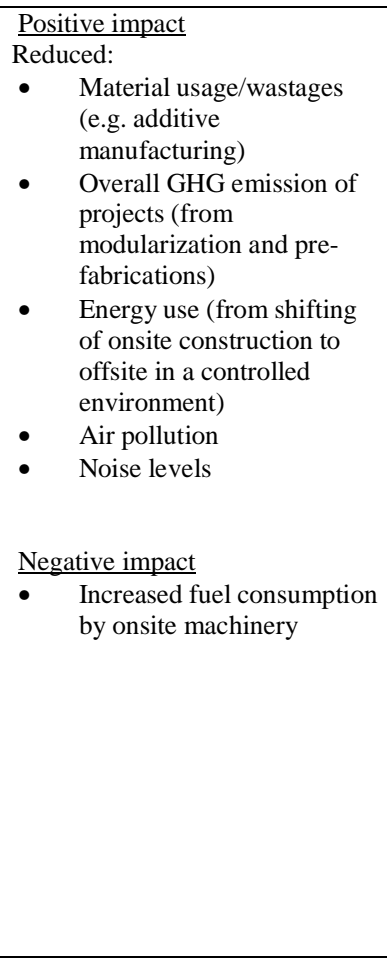 & $\begin{array}{l}\text { Positive impact } \\
\text { Reduced: } \\
\text { - } \quad \text { Manual errors and reworks } \\
\text { structures) } \\
\text { Worker fatigue (heavy manual lifting can } \\
\text { be carried out by robots) } \\
\text { Gender gap in construction as automation } \\
\text { creates new jobs for women. } \\
\text { Creation of new jobs (e.g., drone pilots, } \\
\text { remote operators) } \\
\text { Improvement in product quality } \\
\text { Opskilling of workers } \\
\text { contractors (depending on project progress) } \\
\text { facilitated (via smart contracts) } \\
\text { Negative impact } \\
\text { Increased job losses, especially blue collar } \\
\text { workers and site inspectors } \\
\text { Smaller firms disadvantaged (due to high } \\
\text { cost of technology implementation); may } \\
\text { go out of business due to inability to keep } \\
\text { pace with (new) technology. } \\
\text { Local firms may lose out to foreign firms } \\
\text { in project tenders (given that the latter } \\
\text { would have superior technical know-how) } \\
\text { Disparity in salaries may increase (with } \\
\text { employees with ICT knowledge tending to } \\
\text { get paid more) }\end{array}$ & $\begin{array}{l}\text { Positive impact } \\
\begin{array}{l}\text { Increase in productivity and } \\
\text { efficiency }\end{array} \\
\text { Lower overall cost of projects } \\
\text { Negative impact } \\
\begin{array}{l}\text { High upfront cost of } \\
\text { implementation }\end{array}\end{array}$ \\
\hline \multicolumn{5}{|c|}{ Integration and Collaboration } \\
\hline & $\begin{array}{l}\text { Building } \\
\text { Information } \\
\text { Modelling (BIM) } \\
\text { Cyber-Physical } \\
\text { Systems (CPS) } \\
\text { Blockchain } \\
\text { Digital Twins } \\
\text { Geographical } \\
\text { Information } \\
\text { Systems (GIS) }\end{array}$ & $\begin{array}{l}\text { Positive impact } \\
\text { Improved overall } \\
\text { performance due to } \\
\text { advanced modeling and } \\
\text { simulation at the design } \\
\text { stage itself (e.g, Integration } \\
\text { of life cycle analysis in } \\
\text { BIM modeling) } \\
\text { Significantly lower input } \\
\text { material requirements; also, } \\
\text { reduced material wastages } \\
\text { (from real-time visibility } \\
\text { and information exchange } \\
\text { between the physical and } \\
\text { cyber space). }\end{array}$ & $\begin{array}{l}\text { Positive impact } \\
\text { - } \quad \begin{array}{l}\text { Increased stakeholder communication and } \\
\text { collaboration }\end{array} \\
\text { Increased employee productivity with } \\
\text { virtual and robotic co-worker assistance. } \\
\text { Negative impact } \\
\text { - } \quad \text { Increased vulnerability to cyber attacks } \\
\text { Heightened exposure to radiation (from } \\
\text { sensors and electronic equipment) } \\
\text { Reduced creativity of employees (as they } \\
\text { will be heavily influenced and shaped by } \\
\text { the technologies themselves; e.g. designers }\end{array}$ & $\begin{array}{l}\text { Positive impact } \\
\text { Lower cost for making physical } \\
\text { prototypes and model (e.g., } \\
\text { Digital twins) } \\
\text { Buildings could be designed in } \\
\text { a way that they are value } \\
\text { engineered and optimized for } \\
\text { every stage of construction, } \\
\text { operation, and end of life } \\
\text { demolition (via advanced } \\
\text { modeling and simulation) } \\
\text { Costly design variations at } \\
\text { advanced stages of project } \\
\text { could be avoided (via features }\end{array}$ \\
\hline
\end{tabular}




\begin{tabular}{|c|c|c|c|c|}
\hline & & Environmental & Social & Economic \\
\hline & & 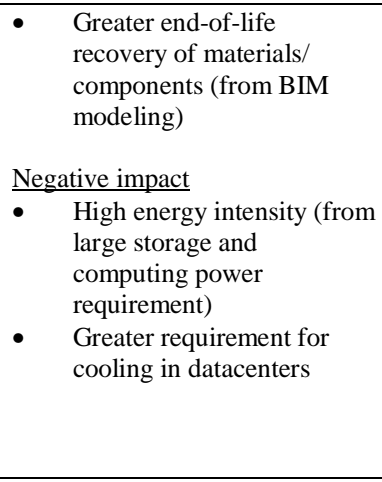 & $\begin{array}{l}\text { will be forced to design in a way that the } \\
\text { system permits) } \\
\text { Technology owners such as Autodesk } \\
\text { becoming more powerful who would be } \\
\text { driving the sector in a direction they } \\
\text { envision, which will be more economic } \\
\text { and less socio-environmental oriented. }\end{array}$ & $\begin{array}{l}\text { such as automatic clash } \\
\text { detection) } \\
\text { Fake and counterfeit products } \\
\text { could be reduced (via } \\
\text { Blockchain technology) } \\
\text { Negative impact } \\
\text { - } \quad \begin{array}{l}\text { Some technologies are } \\
\text { relatively new, and may be } \\
\text { prone to failure. } \\
\text { Longevity of the new } \\
\text { technologies is relatively } \\
\text { unknown (and especially in } \\
\text { relation to the long life-cycle of } \\
\text { buildings) }\end{array} \\
\end{array}$ \\
\hline \multicolumn{5}{|c|}{ Intelligent Environment } \\
\hline & $\begin{array}{l}\text { Machine } \\
\text { Learning } \\
\text { Artificial } \\
\text { Intelligence } \\
\text { Intelligent } \\
\text { Buildings, Smart } \\
\text { Construction } \\
\text { Sites, Smart } \\
\text { Materials } \\
\text { Simulation } \\
\text { (Discrete-event } \\
\text { and agent-based) } \\
\text { Cyber-security }\end{array}$ & $\begin{array}{ll}\text { Positive impact } \\
\text { - } & \begin{array}{l}\text { Waste reduced/eliminated } \\
\text { (via ML and AI) }\end{array} \\
\text { Lower energy consumption } \\
\text { via intelligent heating, } \\
\text { ventilation and cooling } \\
\text { through AI) } \\
\text { Lower electricity } \\
\text { consumption (by intelligent } \\
\text { demand and supply } \\
\text { management energy grids) } \\
\text { Lower environmental } \\
\text { footprint through smart } \\
\text { materials; e.g. self-cleaning } \\
\text { windows with lower water } \\
\text { consumption and photo- } \\
\text { voltaic glass facades that } \\
\text { generate clean solar energy } \\
\text { Negative impact } \\
\text { Bigger datacenters needed } \\
\text { (given complex ML and AI } \\
\text { algorithms require } \\
\text { significant computational } \\
\text { power) } \\
\text { Greater e-waste }\end{array}$ & $\begin{array}{l}\text { Positive impact } \\
\text { - } \quad \begin{array}{l}\text { Lower onsite accidents and loss of life } \\
\text { Creation of new jobs for machine learning } \\
\text { and artificial intelligence professionals. }\end{array} \\
\text { Negative impact } \\
\text { - } \begin{array}{l}\text { Professional autonomy and creativity of } \\
\text { employees reduced (because of too much } \\
\text { technology guidance) }\end{array} \\
\text { Lower self-actualization and self-worth of } \\
\text { employees (from the new role of 'robotic } \\
\text { coordinators') }\end{array}$ & $\begin{array}{ll}\text { Positive impact } \\
\text { - } & \begin{array}{l}\text { Significant efficiency gains } \\
\text { (from ML and AI driven } \\
\text { optimization of construction } \\
\text { processes) }\end{array} \\
\text { - } & \begin{array}{l}\text { Hidden (inefficient) resource } \\
\text { spending patterns, which may }\end{array} \\
\text { otherwise go unnoticed, can be } \\
\text { tracked and improved. } \\
\text { - Long term savings (from smart } \\
\text { materials) } \\
\text { Significantly reduced manual } \\
\text { labor costs (from smart } \\
\text { construction sites) } \\
\text { Lower human bias and } \\
\text { subjectivity in decision-making } \\
\text { Negative impact } \\
\text { Over-reliance on technology } \\
\text { can lead to costly delays and } \\
\text { disruptions in the case of } \\
\text { technology failure }\end{array}$ \\
\hline
\end{tabular}

thereby significantly reducing the travel-related and eventrelated environmental footprint, highlighting the opportunities of augmented and virtual reality in the construction sector (Ahmed, 2018).

Several respondents highlighted the advances in modular designs that facilitate offsite pre-fabrication of building components that significantly lower onsite construction waste, one of the major environmental concerns of the construction sector. According to them, pre-fabricated materials in a controlled environment are likely to have lower embodied energy than onsite construction. This echoes the growing trend in applying off-site construction practices (Moon et al., 2020). Further, developers and architects/consultants are using BIM for building design that allows easy disassembly during the end of life, maximizing recovery and recyclability of materials and components. One respondent (a main contractor) shared his experience using photo-voltaic glass facades that generate clean energy in one of their high-rise building projects. Other respondents highlighted the advances in solar panel technology for harnessing clean energy in project sites and buildings. Other respondents highlighted the potential of $\mathrm{AI}$ in facilitating intelligent, heating, ventilation, and cooling solutions, thereby lowering the environmental footprint.

Negative Environmental Implications - Industry 4.0 technologies have some adverse impacts on the environment. Interviewees highlighted the power-hungry nature of these technologies. For instance, machine learning and AI algorithms require a significant amount of computational power, thereby increasing the need for powerful servers. Large data centers with extensive cooling requirements are required for storing and computing the significant amount of data generated. However, most respondents mentioned that they have either migrated or are in the process of migrating to cloud data centers instead of on-premises data centers. Some respondents are particular in selecting cloud service providers such as Microsoft, which is committed to $100 \%$ renewable energy in all of its data centers by 2025, thereby reducing their organizational footprint. Previous studies have reported similar 
concerns about the high computational energy demand for AI and big data analytics (Beltrami et al., 2021). The other problem highlighted by respondents is the significant electronic waste (e-waste) generated at construction sites. Ironically, most IoT devices (some of them deployed to manage construction waste) end up in landfills after their useful life. Also, most of them are battery-powered, leading to a significant increase in toxic battery waste. Other sectors have also reported similar negative impacts on the environment, such as increased electronic waste and increased energy consumption (Ejsmont et al., 2020).

\section{2) Social sustainability implications}

Comparable positive and negative impacts of Construction 4.0 technologies are identified for social sustainability.

Positive Social Implications - In terms of positive implications, the consensus among interviewees was that Construction 4.0 does improve the health and safety of workers. This is promising, because the construction sector constituted the largest percentage (47\%) of the total number of worker deaths by accidents in the UAE (SCAD, 2014). The primary reasons for these deaths are fall from height, being hit by moving objects, being caught, crushed, squeezed, compressed, or pinched between two or more objects (caught-in or caughtbetween accidents).

According to interviewees, accidents and injuries will significantly reduce with the use of technology. One respondent pointed out their use of drones for distant inspections and lifting of objects in high-rise towers. Similarly, another respondent highlighted the use of 'climbing robots' for cleaning windows of high-rise buildings, thereby replacing humans in this highrisk occupation. Automation of onsite construction activities by intelligent machines can facilitate sensing the presence of workers in dangerous proximity and can warn the operator or the machine involved can stop itself, significantly reducing caught-in or caught-between accidents. Previous studies have advocated using Construction 4.0 technologies to eliminate human error as much as possible and prevent accidents (Akyazi et al., 2020; Turner et al., 2021).

Similarly, sensor-based smart construction sites that can detect noise levels and pollution levels can improve onsite workers' mental and physical well-being. One respondent highlighted the use of smart wearables such as digital wrist bands and smartwatches that can detect if workers are tired or overworked. On similar lines, another respondent noted their use of smart cameras attached to workers' helmets, which is used for remote supervision and training programs. Interviewees also expressed their optimism in shifting all the manual repetitive, and heavy lifting jobs from humans to robots at construction sites, thereby minimizing the sector's high dependence on blue-collar workers, which has been a subject of heavy criticism in the past. One interviewee (a main contractor) mentioned that they had initiated a comprehensive program for upskilling blue-collar workers to knowledge workers. This echoes the evidence from other sectors related to Industry 4.0's positive impact on employee morale, safer working conditions, less intense workload, and job enrichment (Furstenau et al., 2020; Margherita and Braccini, 2020)

Another positive theme that emerged during the interviews is the overwhelming potential of Construction 4.0 in enhancing gender diversity in construction. At present, more than $90 \%$ of the UAE workforce in the UAE construction sector are male (Construction Week, 2020). Most of the female jobs are backoffice jobs in administrative or secretarial posts. According to interviewees, this gap is largely due to the stereotypes and social perceptions that the construction sector is tough and dangerous for women. However, with Construction 4.0, respondents believe that the nature of new jobs in the construction sector will be more attractive and conducive for women. This will support the UAE's vision of becoming one of the top countries for gender equality (OECD, 2017) as well as keeping to the country's overall UN sustainable development goals. This is also in line with previous findings that Construction 4.0 could help reduce the gender divide of the sector through increased participation of females (Barrett, 2020).

Counterfeit building materials continue to represent a threat to the construction industry in the UAE and elsewhere (Construction Week, 2017). The stiff competition and lowprofit margins are reasons for the increasing unlawful trading of cheap and counterfeit products. The interviewees highlighted that the advancement in IoTs, 4G/5G mobile technology, and blockchain could significantly improve the end-to-end supply chain traceability of illegal and counterfeit goods, thereby improving construction quality. The interviewees also expressed optimism in the advancements in BIM and blockchain in enhancing early collaboration between different supply chain stakeholders. Previously, lack of stakeholder collaboration was identified as one of the key challenges of the UAE construction sector (Balasubramanian and Shukla, 2017a; 2017b). Examining the broad application of Construction 4.0 at the supply chain level (which was missing in the construction literature) is encouraging for the sector. Previous studies in other sectors have highlighted the potential of Industry 4.0 in achieving sustainable supply chains (Ejsmont et al., 2020; Beltrami et al., 2021).

Further, blockchain-enabled smart contracts can ensure construction contractors and suppliers are paid on time after receiving the confirmation of completion. This significantly increases the transparency and trust across supply chain stakeholders in a sector that is plagued with payment delays and disputes. In the words of one of the interviewees (a subcontractor): "Cash flow is the essence of our business; already the payment terms are 90 to 180 days, and if these payments are further delayed or caught up in lengthy arbitration, we go out of business". Finally, at the societal level, Construction 4.0 technologies will significantly improve the quality of buildings, and advances in design and smart technology will improve occupants' quality of life, such as improved indoor air quality, natural lighting, and ventilation. Also, Construction 4.0 will create several new classes of jobs for the economy, such as industrial data scientists, drone pilots, remote operators, machine learning, and artificial intelligence professionals. This is in line with previous studies that reported the potential of Industry 4.0 in creating new jobs for the economy (de Soto et al., 2019; Sherratt et al., 2020). 
Negative Social Implications - There are several adverse social implications of Construction 4.0 at the employee level, supply chain level, and societal level. Almost every interviewee expressed their concerns related to the loss of jobs, especially those of blue-collar workers. In the words of one of the respondents: "We hear buzz words such as upskilling and reskilling workforce and that only the nature of jobs will change... the reality is millions of unskilled blue-collar workers will lose not only their jobs but also their livelihoods as they become unemployable... it is difficult to train them, especially if they are old". One respondent highlighted that most bluecollar workers are not even aware that they will become redundant soon, and no one has even warned them. Another respondent added that in addition to blue-collar workers, several site inspectors, supervisors will also lose their jobs as these roles can be easily replaced with technology as well. At the broader societal level, the main concern is that these expatriate blue-collar workers are the sole breadwinners of their families back in countries such as India, Pakistan, Bangladesh, and Nepal, and the roll-out of Industry 4.0 technologies will lead to mass repatriation of these workers. Previously, a number of authors have identified the loss of jobs as a key threat to the implementation of construction 4.0 (Adepoju and Aigbavboa, 2020a; Chan, 2020; Forcael et al., 2020; Mansouri et al., 2020). For example, implementing digital twin technology will reduce the number of employees needed by automating or augmenting several functions in construction currently performed by people, such as planning, coordinating, communicating, measuring, checking, and inspecting (Sacks et al., 2020).

The other emergent theme from the interviewees is the increase in employee surveillance. Most respondents are concerned that these technologies can be used to increase surveillance, such as tracking their movements at construction sites. This will be a significant deterrent to employee freedom and morale. This also raises questions on employee privacy as many of them are unaware that they are closely monitored. The other theme that emerged from the interviews is the fact that the creativity of employees is adversely affected by technology. The interviewed architects and consultants, in particular, expressed their concerns about how their creativity, freethinking, and skills are being influenced and shaped by these technologies (e.g., designers are forced to design in the way the system permits). Intentionally or unintentionally, such technologies are weakening the professional autonomy and creativity of employees, adversely impacting their perceived self-worth at the workplace. The results support the notion in the literature that employees' privacy will be overrun by technology-based monitoring/surveillance and that employment relationships can be negatively affected (Adepoju and Aigbavboa, 2020a; Calvetti et al., 2020). The other concern expressed by interviewees is that Construction 4.0 technologies will further enhance the digital divide. Those with information and communication technology (ICT) skills and expertise are likely to benefit more from these advancements than others. This will lead to inequalities at the workplace in terms of wages and career advancements. Employees from developed countries will have an unfair advantage over those from developing or underdeveloped countries (Ghobakhloo, 2020).

At the firm level, one of the main concerns of Industry 4.0 technologies is cybersecurity. According to interviewees, cyber-attacks, as well as intentional and unintentional internal and external data breaches, pose a significant challenge on data privacy and loss of technological knowledge intended to stay within the firm. Previous studies have highlighted cybersecurity threats as one of the main concerns of Construction 4.0 (Newman et al., 2020; Mantha et al., 2021). One of the respondents noted that the collaborative nature of technology such as BIM, in which numerous stakeholders are connected, increases the data security breach risks. In the words of one interviewee: "...the security is only as strong as its weakest link in collaborative projects". Previous studies have reported that the Industry 4.0 technologies such as the blockchain and IoTbased ecosystem are immature, with multifaceted trust issues at all levels, from technology providers to users and governments (ur Rehman et al., 2020; Lockl et al., 2020). The other unique concern that emerged from the interviews is that 'technology owners' such as Autodesk are becoming more powerful and are driving the sector in the direction they envision, which is driven more from an economic standpoint and less from a socioenvironmental perspective.

A few respondents (from SME) highlighted the widening digital divide between large and smaller firms in implementing Industry 4.0. Large firms are better positioned than smaller firms to benefit from Industry 4.0 technologies because of their superior financial and human resources. The interviewee expressed his concern that smaller firms may not keep up with the latest technologies, which can require a significant upfront investment. Given that SMEs make up more than $95 \%$ of firms in the UAE, the inclusion of SMEs in the Industry 4.0 discourse is critical for sector-wide adoption (Dubai SME, 2019). Along similar lines, the digital divide between foreign and local firms is a concern. When probed, several respondents from local firms expressed their worries that foreign firms (from developed countries) are likely to benefit more from Industry 4.0 because of their superior capabilities, technical and managerial know-how.

3) Economic sustainability implications

Similar to environmental sustainability, the overall results (see Table V) show that the positive economic impacts from Construction 4.0 outweigh the negative ones.

Positive Economic Implications - The positive economic impact of Construction 4.0 is mainly because the positive environmental benefits get translated as economic benefits. For example, significant savings in energy, water, materials, and human resources from Industry 4.0 technology will reduce the cost of construction projects and the operational costs of buildings. Similarly, social benefits also get translated as economic benefits. For instance, improvement in health and safety from Construction 4.0 will significantly reduce the downtime in construction sites due to injuries or fatalities. According to respondents, one of the main benefits of Industry 4.0 technology is the reduction in costs, including manual labor costs, inspection and supervision costs, and savings from the automation of routine administrative tasks, which will also 
bring down the overall construction costs.

Further, advanced modeling and simulation allow building design to be value-engineered and optimized for every stage of construction, operation, and end-of-life demolition. It also allows designers to simulate various scenarios and check for any conflicts in materials or processes during the implementation phases, significantly reducing the costly design variations and reworks at advanced stages of the project. During construction, AI-based tools could detect possible crashes, delays, and changes in the construction process by comparing the digital twin of the building against the physical one. Previous studies have reported that artificial intelligence, and machine learning algorithms can accurately predict project costs (Elmousalami, 2021). Similarly, interviewees reported using drones to take images and conduct laser scans of the project site, which were used to check project progress, errors, and variation from the digital twin stored in the BIM cloud. The results support the growing use of drones at construction sites, as it significantly reduces the efforts required in conventional construction monitoring and reporting procedures (Adepoju and Aigbavboa, 2020a).

Construction 4.0 technologies were found to improve employee productivity. One respondent (a main contractor) highlighted their use of asset tagging using RFID technology at the construction site to reduce the time spent searching/acquiring equipment for project teams, thereby improving employee productivity. It also enables them to share resources across different projects efficiently. The same respondent also noted the potential of asset tagging and other technologies such as geofencing in reducing theft and misplacement of materials. The findings support the overwhelming evidence in the literature that Construction 4.0 can improve employee productivity and efficiency (Cai et al., 2019; Maskuriy et al., 2019; Calvetti et al., 2020b).

Similarly, the use of advanced materials such as self-healing concrete can considerably reduce the life-cycle costs of buildings by eliminating costly retrofits during the operational phase. One respondent noted the significant cost-reduction potential of self-cleaning glass facades. Similarly, advances in solar panel technology will also reduce the operational energy costs of buildings. Two respondents highlighted the potential of VR and AR technology in creating immersive training programs for employees, significantly reducing the cost of faceto-face classroom-based training. Advanced analytics enable real-time monitoring and detection of resource wastages and inefficiencies in the construction project. Real-time monitoring of project progress enables just-in-time procurement and inventory optimization. Also, during the operational phase, machine learning and AI algorithms can detect parts of buildings that are currently not being used and automatically deactivate the heating, ventilation, and air conditioning in these parts, drastically reducing energy consumption costs. Similarly, IoT sensors can facilitate predictive maintenance instead of routine preventive maintenance, which significantly reduces the total cost of ownership by avoiding unnecessary maintenance of unused or less used parts of the building. Previous studies have reported lifecycle cost savings due to preventive and predictive measures afforded by Construction 4.0 technologies (Muñoz-La Rivera et al., 2021; Forcael et al., 2020).

Negative Economic Implications - There are a few adverse economic implications of Construction 4.0. The interviewees noted that the cost of cyber-attacks and data breaches would be huge, including reputational loss. One respondent reminded that the integrated nature of technology means that any failure could have a cascading effect on others, leading to significant disruptions and delays. This was echoed by another interviewee who highlighted the over-reliance on BIM technology. Further, given the collaborative nature of BIM across the developer, designer, contractor, and sub-contractor, in the case of design failures, who takes responsibility and liability for claims is blurred. Also, conflicting interests among collaborative teams could lead to a lack of consensus and project delays in the design approval. These results support the notion in the literature that uncertainty about the Construction 4.0 technologies may affect its acceptance (Newman et al., 2020).

The other common concern that emerged from the interviews is the high upfront cost of implementing the Construction 4.0 technologies, echoing the concerns in the literature (Adepoju and Aigbavboa, 2020a). As mentioned earlier, smaller firms may struggle both on a financial and human resource front to implement Construction 4.0 technologies. One of the respondents (in the small and medium firms category) expressed his concern about the return on investment of Construction 4.0 technologies, as smaller firms do not have adequate scale economies compared to large firms. Another respondent expressed concern over the hidden and recurring costs of technologies, such as annual subscription charges, employee training costs, cyber-security costs, and ICT upgrade costs. Some interviewees highlighted the significant increase in the human resource budget for hiring and training technology professionals. The results resonate with the concern in the literature that adoption of Construction 4.0 may lead to high costs in possessing and operating technology, since some technology may require constant enhancement or evolution (Newman et al., 2020; Osunsanmi et al., 2020). Similarly, Karadayi-Usta (2020) reported a lack of financial resources as one of the key adoption challenges of Industry 4.0.

\section{CONCLUSIONS}

It has only been a few years since the construction sector started taking Industry 4.0 technologies seriously. Yet, no comprehensive evidence-based and structured approach has been made, first to identify the various isolated technologies, and then to assess their current and future implementation potential as well as their contribution towards sustainable development. In line with the research questions, the study identifies various Construction 4.0 technologies along with their future prospects and examines their impact on environmental, social, and economic sustainability. A comprehensive, Construction 4.0 sustainability framework with the potential to be applied to any country context was developed in this study. The usefulness and applicability of the framework were demonstrated in a real-life setting through a case study of the UAE construction sector. In the process, the authors have 
identified several trends, consensus, conflicts, approaches, methods, and gaps, all of which help to understand better and improve the adoption of Construction 4.0 technologies and guide future research.

The implications of this study are manifold. For its research implications, the study is the first comprehensive attempt to link Construction 4.0 with all three dimensions of sustainability (environmental, economic, and social). Also, the study is the first comprehensive empirical investigation of Construction 4.0 in the UAE construction sector. First, the authors were able to identify and integrate various isolated Industry 4.0 technologies into meaningful and managerially relevant categories, namely, digitalization, automation and advancement manufacturing, integration and collaboration, and intelligent environment. Moreover, unlike previous studies, a balanced approach was taken to assessing both the positive and negative implications of Construction 4.0 technologies. The findings are, therefore, both novel and significant. The study also provides some degree of consensus as to the scientific contours of Construction 4.0.

In terms of practical implications, this research demonstrates that Construction 4.0 has enormous potential to transform the sector and address some of its pressing environmental and socio-economic problems. Given that most of the underlying issues in construction are similar in most countries, the insights obtained from this study can be used as a good starting point for practitioners and policymakers in other countries to leverage Construction 4.0 technologies while addressing its negative environmental, social, and economic implications. However, not all the Industry 4.0 technologies and sustainability implications mentioned in the study may be relevant for developing or underdeveloped countries. For such countries, cost-effective technologies such as RFID may be more suitable. Similarly, the focus of such countries may be predominantly on economic and social aspects. Therefore, the study findings and framework may require adaptation to their respective country contexts. The results are helpful for governments and professional associations for defining roadmaps, and developing supportive regulations, policies, and guidelines for the sector-wide adoption of Construction 4.0. The study is also timely, given that the global spread of the COVID-19 pandemic has forced the construction sector worldwide to find safer and smarter ways to build using Construction 4.0 technologies (e.g., 3D printing, use of drones for site surveillance) due to the increasing cost of raw materials, forced reduction in onsite labor to implement social distancing measures, budget constraints, project delays, and other factors.

From the environmental sustainability standpoint, it was found that the benefits of Construction 4.0 far outweigh its negative impact on the environment. Its ability to gather precise, real-time data and then use analytics to garner deep insights on material, water, and energy consumption patterns and waste statistics could significantly improve the sector's environmental sustainability. However, the sector needs to address the challenges of e-waste generated at the site, including recycling and safe disposal, rather than sending it to landfills. Similarly, the sector must take actions to minimize the environmental impact arising from the power-hungry nature of these technologies, such as by using renewable energy to power the datacenters.

With regard to social sustainability, we found both several positive and negative implications. The positive implications include the improved health and safety of workers. This is promising, because construction is one of the sectors that constitute the largest percentages of worker death by accidents and injuries in the UAE and elsewhere. Moreover, Construction 4.0 will generate several new types of jobs, especially jobs in science and technology. Many of these will be more attractive to and conducive for women, thereby enhancing the muchneeded gender diversity in construction, a sector in which more than $90 \%$ of the workforce in the UAE is male. Further, at the supply chain level, advances in technology such as blockchain could significantly improve the end-to-end supply chain traceability of illegal and counterfeit goods, thereby improving the build quality of construction.

However, there are several adverse societal implications of Construction 4.0. More discourse from an ethical and humanitarian perspective is required on the potential loss of jobs of unskilled blue-collar workers and their future role in the sector due to Construction 4.0. An increase in the surveillance of employees raises questions on employee freedom and privacy. Also, more discourse is required on the data-related privacy, cyber-security, and data breaches surrounding Construction 4.0. Similarly, the sector needs to examine the potential weakening of employees' professional autonomy and creativity, especially that of designers, and the subsequent implications in terms of impact on such employees' perceived self-worth at the workplace.

Further, Construction 4.0 is widening the corporate divide between large firms and small firms due to the differential ability of these firms to invest in innovative technologies. Specifically, large firms exhibited significantly greater levels of Construction 4.0 adoption than smaller firms. Given that SMEs make up more than $90 \%$ of firms globally, the inclusion of SMEs in the Construction 4.0 discourse is critical for sectorwide adoption. Governments must provide support mechanisms, such as financial support, incentives, tax discounts, and training, to increase their adoption of Construction 4.0 technologies. A similar corporate divide between foreign and local firms is witnessed. Therefore, to promote sector-wide Construction 4.0 implementation, policymakers and industry groups must initiate various programs and collaborative partnerships to facilitate the transfer of relevant knowledge, expertise, and skills from foreign firms to local firms, such as through local-foreign joint ventures and foreign firms mentoring local firms. From a foreign policy perspective, this shows that countries looking to promote Construction 4.0 should encourage foreign firms, especially those from developed countries, to establish subsidiaries there.

Finally, from an economic sustainability standpoint, again, the benefits of Construction 4.0 far outweigh its negative impact. However, given the collaborative nature of Construction 4.0, such as BIM, mechanisms must be devised to share the profits or losses from the project based on the extent of collaboration. This can significantly improve the inherent 
concerns related to accountability and the low profit margin of the sector.

The study has some limitations. Although the proposed framework was developed based on an extensive review, it may not cover every facet of Construction 4.0. Also, the application of the framework was tested only in a single country. Furthermore, the application was demonstrated through a predominantly qualitative approach, and therefore statistical/quantitative precision in validating the framework is missing.

For future research, given the framework's conceptual comprehensiveness and generic nature, researchers in different industrial settings could adapt and use the framework in their respective contexts. Also, given the complexity of the construction sector, which includes architects/consultants (service providers), contractors/sub-contractors (integrators), and (material and equipment) suppliers, the study mirrors a broad spectrum of different sectors and industries and, therefore, the potential applicability of the framework to other sectors is high, provided applications are carefully crafted and contextualized. Furthermore, future research could apply more rigor in the primary investigation and potentially involve conducting a large-scale survey-based study to test the statistical appropriateness and generalizability of the framework in different settings and to examine the causal link between Construction 4.0 implementation and its impact on environmental, social, and economic sustainability. Moreover, given that Construction 4.0 is a relatively new and promising domain, future studies could attempt to strengthen and complement the proposed framework and study findings through refinement and validation across countries and test its usefulness and applicability.

Despite these limitations, we believe the proposed framework and its successful application will significantly enhance the understanding of Industry 4.0 in the construction sector. We anticipate that this study will encourage more research on Construction 4.0 and Industry 4.0 in general, and contribute to the theoretical advancement in the field.

\section{APPENDIXES}

Appendix 1: Interview Protocol

- What are the various Construction 4.0 technologies implemented by your firm?

- To what extent do you implement these technologies?

- Why did you implement these technologies over others?

- Did you face any challenges while implementing these technologies? If so, what are they?

- Based on your experience with the implementation of various Construction 4.0 technologies, what are their positive impacts on triple bottom line of sustainability (environmental, social, and economic aspects)? Please provide few examples.

- Based on your experience with the implementation of various Construction 4.0 technologies, what are their negative impacts on triple bottom line of sustainability (environmental, social, and economic aspects)? Please provide few examples.

- How do you foresee the application of Construction 4.0 in the next 5 years?
Appendix 2: Survey Instrument

Q1 How many years of experience do you have in the construction sector?

o 0-2 Years

o 3-5 Years

o 6-10 Years

o 10-15 Years

o 15-25 Years

o Above 25 Years

o I do not work in the construction or related sector

Skip to: End of Survey If How many years of experience do you have in the construction sector? = I do not work in the construction or related sector

Q2 Your Gender

o Male

o Female

Q3 Your Age

o $18-24$

o $25-34$

o $35-44$

o $45-55$

o Above 55

Q4 Please mention your role/position level in the organization

o Entry / Junior Level

o Mid-Level

o Senior Level

o Top management / leadership team

o Others (Please specify)

Q5 Your educational level

o High School/Diploma

o Bachelor's Degree

o Master's Degree or above

o Others (Please specify)

Q6 Please rate the extent of adoption of Construction 4.0 technologies at present in the UAE construction on a scale of 15 (1- Not considered at all; 5 - Highly considered) as well as the likely adoption in the next 5 years ( 1 - Not at all; 5 - To very high extent). Please enter the response as a numeric value.

\begin{tabular}{|l|l|l|}
\hline Construction 4.0 Technologies & Present Adoption (1-5) & Future Adoption (1-5) \\
\hline 3D Laser Scanning and Photogrammetry & & \\
\hline 3D Printing (Additive Manufacturing) & & \\
\hline Artificial Intelligence & & \\
\hline Automation using Robotics (Off-site) & & \\
\hline Automation using Robotics (Onsite) & & \\
\hline Autonomous onsite vehicles & & \\
\hline Big Data Analytics & & \\
\hline Blockchain & & \\
\hline Building Information Modeling & & \\
\hline Cloud Computing & & \\
\hline Cyber-Physical Systems (CPS) & & \\
\hline Drones & & \\
\hline Internet of Things (IoTs) & & \\
\hline Machine Learning & & \\
\hline Smart Construction Sites & & \\
\hline Smart Contracts & & \\
\hline Smart Materials (e.g., Self-healing, Self-Cleaning materials) & & \\
\hline Virtual and Augmented Reality & & \\
\hline
\end{tabular}




\section{REFERENCES}

Adepoju, O.O. and Aigbavboa, C.O., 2020a. Implementation of Construction 4.0 in Nigeria: Evaluating the Opportunities and Threats on the Workforce. Academic Journal of Interdisciplinary Studies, 9(5), pp.254-254. Adepoju, O.O. and Aigbavboa, C.O.,2020b. Assessing knowledge and skills gap for Construction 4.0 in a developing economy. Journal of Public Affairs, p.e2264

Ahmed, S., 2018. A review on using opportunities of augmented reality and virtual reality in construction project management. Organization, technology \& management in construction: an international journal, 10(1), pp.1839-1852. Akyazi, T., Alvarez, I., Alberdi, E., Oyarbide-Zubillaga, A., Goti, A. and Bayon, F., 2020. Skills Needs of the Civil Engineering Sector in the European Union Countries: Current Situation and Future Trends. Applied Sciences, 10(20), p.7226.

Arabian Business., 2018. Abu Dhabi deploys drones to inspect construction sites. Available at https://www.arabianbusiness.com/technology/401936-wkdabu-dhabi-deploys-drones-to-inspect-construction-sites

Bag, S., Yadav, G., Dhamija, P. and Kataria, K.K., 2021. Key resources for industry 4.0 adoption and its effect on sustainable production and circular economy: An empirical study. Journal of Cleaner Production, 281, p.125233.

Bag, S., Yadav, G., Wood, L.C., Dhamija, P. and Joshi, S., 2020. Industry 4.0 and the circular economy: resource melioration in logistics. Resources Policy, 68, p.101776.

Balasubramanian, S. and Shukla, V., 2017a. Green supply chain management: an empirical investigation on the construction sector. Supply Chain Management: An International Journal, 22(1), pp. 58-81.

Balasubramanian, S. and Shukla, V., 2017b. Green supply chain management: the case of the construction sector in the United Arab Emirates (UAE). Production Planning \& Control, 28(14), pp.1116-1138.

Balasubramanian, S., Shukla, V., Sethi, J.S., Islam, N. and Saloum, R., 2021. A readiness assessment framework for Blockchain adoption: A healthcare case study. Technological Forecasting and Social Change, 165, p.120536.

Barrett, J., 2020. Choose your future: a feminist perspective on Construction 4.0 as techno-utopia or digital dystopia. Proceedings of the Institution of Civil Engineers-Management, Procurement and Law, 173(4), pp.153-157.

Bashir, A. and Kivrak, S., 2020. Investigating engineer's actual usage intention to apply construction technologies in emerging countries. Journal of Measurements in Engineering, 8(3), pp.80-89.

Beltrami, M., Orzes, G., Sarkis, J. and Sartor, M., 2021. Industry 4.0 and sustainability: Towards conceptualization and theory. Journal of Cleaner Production, p. 127733.

Boton, C., Rivest, L., Ghnaya, O. and Chouchen, M., 2020. What is at the Root of Construction 4.0: A systematic review of the recent research effort. Archives of Computational Methods in Engineering, pp.1-20.

Bryman, A., 2016. Social research methods. 5th Edition, Oxford university press, New York

Cai, S., Ma, Z., Skibniewski, M.J. and Bao, S., 2019. Construction automation and robotics for high-rise buildings over the past decades: A comprehensive review. Advanced Engineering Informatics, 42, p.100989.

Calvetti, D., Magalhães, P.N.M., Sujan, S.F., Gonçalves, M.C. and Campos de Sousa, H.J., 2020a. Challenges of upgrading craft workforce into Construction 4.0: framework and agreements. Proceedings of the Institution of Civil Engineers-Management, Procurement and Law, 173(4), pp.158-165.

Calvetti, D., Mêda, P., Chichorro Gonçalves, M. and Sousa, H., 2020b. Worker 4.0: The future of sensored construction sites. Buildings, 10(10), p.169. Chan, P.W., 2020. Briefing: Industry 4.0 in construction: radical transformation or restricted agenda?.Proceedings of the Institution of Civil EngineersManagement, Procurement and Law, 173(4), pp.141-144

Conmix . 2020. Conmix signs agreement with basilisk self-healing concrete as their exclusive agents for UAE. Accessed on: Jan. 21, 2021. [Online] Available: https://www.conmix.com/news/conmix-signs-agreement-basiliskself-healing-concrete-exclusive-agents-uae/

Construction Week Online., 2017. A pan-GCC plan could curb the sale of counterfeit building materials. Accessed on: Jan. 13, 2021. [Online]. Available: https://www.constructionweekonline.com/article-44583-a-pan-gcc-plancould-curb-the-sale-of-counterfeit-building-materials

Construction Week Online., 2019a. Inside a Dubai MEP company's modular design factory in Jebel Ali. Accessed on: Jan. 16, 2021. [Online]. Available: https://www.constructionweekonline.com/products-services/168757-a-lookinside-bk-gulfs-game-changing-modular-construction-mep-factory-in-jebel-al Construction Week Online., 2019b. ALEC deploys robotics to build Dubai's \$1bn Marina Gate. Accessed on: Jan. 16, 2021. [Online]. Available: https://www.constructionweekonline.com/projects-tenders/168633-uaecontractor-alec-uses-robotics-to-build-dubai-marina-gate-by-select-group
Construction Week Online., 2019c. How has technology disrupted the Middle East's construction sector? Accessed on: Jan. 16, 2021. [Online]. Available: https://www.constructionweekonline.com/products-services/180835-largeuae-contractors-opt-for-3d-printing-new-tech-to-implement-construction Construction Week., 2020. Gender diversity in construction. Accessed on: Jan. 16, 2021. [Online]. Available: https://www.constructionweekonline.com/business/266369-yovza-outlinesgender-diversity-in-construction

Craveiroa, F., Duartec, J.P., Bartoloa, H. and Bartolod, P.J., 2019. Additive manufacturing as an enabling technology for digital construction: A perspective on Construction 4.0. Automation in Construction, 103, pp.251-267

Dallasega, P., 2018. Industry 4.0 fostering construction supply chain management: Lessons learned from engineer-to-order suppliers. IEEE Engineering Management Review, 46(3), pp.49-55.

de Soto, B.G, Agustí-Juan, I., Joss, S. and Hunhevicz, J., 2019. Implications of Construction 4.0 to the workforce and organizational structures. International Journal of Construction Management, pp.1-13.

DeJonckheere, M. and Vaughn, L.M., 2019. Semistructured interviewing in primary care research: a balance of relationship and rigour. Family Medicine and Community Health, 7(2), 1-8

DEWA., 2017. 3D-Printed Lab at Mohammed bin Rashid Al Maktoum Solar Park. Accessed on: Feb. 12, 2021. [Online]. Available: https://www.dewa.gov.ae/en/about-us/media-publications/latestnews/2017/07/he-saeed-mohammed-al-tayer-visits-3d-printed-lab-atmohammed-bin-rashid-al-maktoum-solar-park

du Plessis, C. and Sherratt, F., 2020. Construction 4.0 and built assets in-use: creating an e-topia or dystopia?. Proceedings of the Institution of Civil Engineers-Management, Procurement and Law, 173(4), pp.182-189.

Dubai 10x., 2020. Accessed on: Jan. 16, 2021. [Online]. Available: https://dubai10x.ae/ Accessed on: Jan. 16, 2021. [Online].

Dubai Future Foundation., 2019. Office of the Future. The World's First 3D Printed Office. Accessed on: Feb. 14, 2021. [Online]. Available: https://www.dubaifuture.gov.ae/our-initiatives/office-of-the-future/

Ejsmont, K., Gladysz, B. and Kluczek, A., 2020. Impact of industry 4.0 on sustainability-bibliometric literature review. Sustainability, 12(14), p.5650.

Elmousalami, H.H., 2020. Comparison of artificial intelligence techniques for project conceptual cost prediction: a case study and comparative analysis. IEEE Transactions on Engineering Management, 68(1), pp.183-196.

FCSA., 2019. Federal Competitiveness and Statistics Authority. Accessed on: Jan. 21, 2021. [Online]. Available: http://fcsa.gov.ae/ar-ae/Pages/home.aspx

Forcael, E., Ferrari, I., Opazo-Vega, A. and Pulido-Arcas, J.A., 2020. Construction 4.0: A literature review. Sustainability, 12(22), p.9755.

Furstenau, L.B., Sott, M.K., Kipper, L.M., Machado, E.L., Lopez-Robles, J.R., Dohan, M.S., Cobo, M.J., Zahid, A., Abbasi, Q.H. and Imran, M.A., 2020. Link between sustainability and industry 4.0: trends, challenges and new perspectives. IEEE Access, 8, pp.140079-140096.

Ghobakhloo, M., 2020. Industry 4.0, digitization, and opportunities for sustainability. Journal of cleaner production, 252, p.119869.

Gulfnews., 2019. UAE is most advanced drones market in Middle East. Accessed on: Feb. 26, 2021. [Online]. Available: https://gulfnews.com/technology/uae-is-most-advanced-drones-market-inmiddle-east-1.2104797

Hoeft, M., Pieper, M., Eriksson, K. and Bargstädt, H.J., 2021. Toward Life Cycle Sustainability in Infrastructure: The Role of Automation and Robotics in PPP Projects. Sustainability, 13(7), p.3779.

Ibrahim, F.S.B., Esa, M.B. and Kamal, E.B.M., 2019. Towards Construction 4.0: Empowering BIM Skilled Talents in Malaysia. International Journal of Scientific \& Technology Research, 8(10), pp.1694-1700.

Immensalabs., 2019. How 3D printing is impacting the construction industry in UAE and globally. Accessed on: Jan. 18, 2021. [Online]. Available: https://www.immensalabs.com/how-3d-printing-is-impacting-the-

construction-industry-in-uae-and-globally/

Kamble, S.S., Gunasekaran, A. and Gawankar, S.A., 2018. Sustainable Industry 4.0 framework: A systematic literature review identifying the current trends and future perspectives. Process Safety and Environmental Protection, 117, pp.408425

Karadayi-Usta, S., 2019. An interpretive structural analysis for industry 4.0 adoption challenges. IEEE Transactions on Engineering Management, 67(3), pp.973-978.

Lavrakas, P.J., 2008. Encyclopedia of survey research methods. Thousand Oaks, CA: Sage publications.

Lekan, A., Aigbavboa, C., Babatunde, O., Olabosipo, F. and Christiana, A., 2020. Disruptive technological innovations in construction field and fourth industrial revolution intervention in the achievement of the sustainable 
development goal 9. International Journal of Construction Management, pp.112 .

Lockl, J., Schlatt, V., Schweizer, A., Urbach, N. and Harth, N., 2020. Toward trust in Internet of Things ecosystems: Design principles for blockchain-based IoT applications. IEEE Transactions on Engineering Management, 67(4), pp.1256-1270.

Mansouri, S., Castronovo, F. and Akhavian, R., 2020. Analysis of the synergistic effect of data analytics and technology trends in the AEC/FM industry. Journal of Construction Engineering and Management, 146(3), p.04019113.

Mantha, B., de Soto, B.G. and Karri, R., 2021. Cyber security threat modeling in the AEC industry: An example for the commissioning of the built environment. Sustainable Cities and Society, 66, p.102682.

Margherita, E.G. and Braccini, A.M., 2020. Organizational impacts on sustainability of industry 4.0: a systematic literature review from empirical case studies. Digital Business Transformation, pp.173-186.

Maskuriy, R., Selamat, A., Ali, K.N., Maresova, P. and Krejcar, O., 2019. Industry 4.0 for the construction industry-How ready is the industry?. Applied Sciences, 9(14), p.2819

MEED., 2019. 3D printing to take over construction. Accessed on: Jan. 20, 2021. [Online]. Available: https://www.meed.com/3d-printing-takeconstruction/

Moon, S., Ham, N., Kim, S., Hou, L., Kim, J.H. and Kim, J.J., 2020. Fourth industrialization-oriented offsite construction: case study of an application to an irregular commercial building. Engineering, Construction and Architectural Management. 27(9), pp.2271-2286.

Morrar, R., Arman, H. and Mousa, S., 2017. The fourth industrial revolution (Industry 4.0): A social innovation perspective. Technology Innovation Management Review, 7(11), pp.12-20.

Munoz-La Rivera, F., Mora-Serrano, J., Valero, I. and Oñate, E., 2021. Methodological-technological framework for Construction 4.0. Archives of Computational Methods in Engineering, 28(2), pp.689-711.

NCSDG., 2018. United Arab Emirates and the 2030 agenda for sustainable development. National Committee on Sustainable Development Goals. Accessed on: Feb. 16, 2021. [Online]. Available: https://fcsa.gov.ae/enus/Documents/UAE\%20SDGs\%20\%E2\%80\%93\%20Executive\%20Summary \%20\%E2\%80\%93\%20VNR\%202018\%20EN.PDF

Newman, C., Edwards, D., Martek, I., Lai, J., Thwala, W.D. and Rillie, I., 2020. Industry 4.0 deployment in the construction industry: a bibliometric literature review and UK-based case study. Smart and Sustainable Built Environment. OECD., 2017. Gender Balance Guide. Accessed on: Jan. 16, 2021. [Online] Available: https://www.oecd.org/gov/gender-balance-guide-uae-2017.pdf

Osunsanmi, T.O., Aigbavboa, C.O., Oke, A.E. and Liphadzi, M., 2020 Appraisal of stakeholders' willingness to adopt Construction 4.0 technologies for construction projects. Built Environment Project and Asset Management. Oztemel, E. and Gursev, S., 2020. Literature review of Industry 4.0 and related technologies. Journal of Intelligent Manufacturing, 31(1), pp.127-182.

Reinhardt, D., Haeusler, M.H., London, K., Loke, L., Feng, Y., De Oliveira Barata, E., Firth, C., Dunn, K., Khean, N., Fabbri, A. and Wozniak-O'Connor, D., 2020. CoBuilt 4.0: Investigating the potential of collaborative robotics for subject matter experts. International Journal of Architectural Computing, 18(4), pp.353-370.

Ribeirinho, M.J., Mischke, J., Strube, G., Sjödin, E., Blanco, J.L., Palter, R. Biörckas, J., Rockhill, D. and Andersson, T., 2020. The Next Normal in Construction: How Disruption is Reshaping the World's Largest Ecosystem. Sacks, R., Brilakis, I., Pikas, E., Xie, H.S. and Girolami, M., 2020. Construction with digital twin information systems. Data-Centric Engineering, 1, pp.1-26 Saunders, M., Lewis, P. and Thornhill, A., 2009. Research methods for business students, 7th Edition. Pearson, Italy.
SCAD., 2014. Occupational Health and Safety. Abu Dhabi Statistics Center. Accessed on: Feb. 27, 2021. [Online]. Available: https://www.scad.gov.ae/Release\%20Documents/Occupational\%20Health\%2 0and\%20Safety\%20eng.pdf

SGER., 2015. State of Green Economy Report. World Green Economy Submit, Dubai, United Arab Emirates. Accessed on: Jan. 16, 2021. [Online]. Available: http://dcce.ae/state-of-green-economy-report-2015/

Sherratt, F., Dowsett, R. and Sherratt, S., 2020. Construction 4.0 and its potential impact on people working in the construction industry. Proceedings of the Institution of Civil Engineers-Management, Procurement and Law, 173(4), pp.145-152.

Statista., 2020. Number of employed persons in the United Arab Emirates in 2019 , by economic sector. https://www.statista.com/statistics/638515/uaetotal-number-of-workforce-by-economic-sector/

Tahmasebinia, F., Sepasgozar, S.M., Shirowzhan, S., Niemela, M., Tripp, A., Nagabhyrava, S. and Alonso-Marroquin, F., 2020. Criteria development for sustainable construction manufacturing in Construction Industry 4.0. Construction Innovation

Turner, C.J., Oyekan, J., Stergioulas, L. and Griffin, D., 2020. Utilizing Industry 4.0 on the Construction Site: Challenges and Opportunities. IEEE Transactions on Industrial Informatics, 17(2), pp.746-756.

UAE Centennial 2071., 2021. Accessed on: Mar. 10, 2021. [Online]. Available: https://u.ae/en/about-the-uae/strategies-initiatives-and-awards/federalgovernments-strategies-and-plans/uae-centennial-2071

UAE MCAF., 2017. UAEs Fourth Industrial Revolution Strategy. UAE Ministry of Cabinet Affairs and the Future. Accessed on: Jan. 22, 2021. [Online]. Available: https://u.ae/en/about-the-uae/strategies-initiatives-andawards/federal-governments-strategies-and-plans/the-uae-strategy-for-the-

fourth-industrial-revolution

UAE MOE., 2019. UAE Economic Report 2019. United Arab Emirates Ministry of Economy. Accessed on: Jan. 21, 2021. [Online]. Available: https://www.economy.gov.ae/EconomicalReportsEn/MOE Annual\%20Econo mic\%20Report_2019_.pdf

UAE., 2020. Emirates Blockchain Strategy 2021. Accessed on: Jan. 21, 2021. [Online]. Available: https://u.ae/en/about-the-uae/strategies-initiatives-andawards/federal-governments-strategies-and-plans/emirates-blockchainstrategy-2021

ur Rehman, M.H., Salah, K., Damiani, E. and Svetinovic, D., 2019. Trust in blockchain cryptocurrency ecosystem. IEEE Transactions on Engineering Management, 67(4), pp.1196-1212.

Vision 2021., 2018. Sustainable Environment and Infrastructure. Accessed on: Jan. 21, 2021. [Online]. Available: https://www.vision2021.ae/en/nationalagenda-2021/list/environment-circle

World Economic Forum., 2020. Inclusive Deployment of Blockchain: case studies and learnings from the United Arab Emirates. Accessed on: Jan. 22, 2021. [Online]. Available: https://www.weforum.org/whitepapers/inclusivedeployment-of-blockchain-case-studies-and-learnings-from-the-united-arabemirates

Yin, R.K., 2009. Case Study Research: Design and Methods. SAGE Publications Ltd, London.

You, Z. and Feng, L., 2020. Integration of industry 4.0 related technologies in construction industry: a framework of cyber-physical system. IEEE Access, 8 , pp.122908-122922.

Zabidin, N.S., Belayutham, S. and Ibrahim, C.K.I.C., 2020. A bibliometric and scientometric mapping of Industry 4.0 in construction. Journal of Information Technology in Construction., 25, pp.287-307. 
Authors' biography

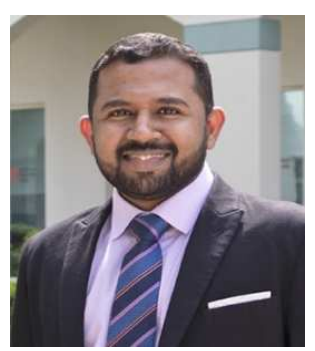

Sreejith Balasubramanian is a Senior Lecturer in Supply Chain Management and Chair of the Research Committee at Middlesex University, Dubai. He completed his $\mathrm{PhD}$ from Middlesex University Business School, London. His areas of expertise include supply chain, operations management, disruptive technologies, sustainability, and knowledge management. His work has been published in leading academic and practitioner-focused journals, including Supply Chain Management: An International Journal, Production, Planning and Control, and Journal of Knowledge Management. He has been a consultant for several public and private sector entities, including the Abu Dhabi Chamber of Commerce and Bridgestone Middleseast.

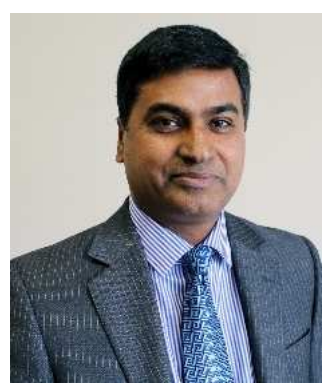

Nazrul Islam is Associate Professor of Innovation/Entrepreneurship and an interdisciplinary pathway lead for global political economy at the University of Exeter Business School, England, UK. He holds a $\mathrm{PhD}$ in innovation management. His research interest focuses on interdisciplinary fields: the management of technology and strategy; innovation and entrepreneurship; the emergence and growth of disruptive and digital technology-based innovation; SMEs business sustainability. His research was published in the leading international journals and he has complemented his peer reviewed journal efforts with three books. Prof Islam's research received awards including the 'Brad Hosler Award for Outstanding Paper' from USA; and the 'Pratt \& Whitney Canada Best Paper Award' from Canada. Prof Islam serves on the board of directors for Business and Applied Sciences Academy of North America. He is an Associate Editor of Technological Forecasting \& Social Change and Editor-inChief of International Journal of Technology Intelligence and Planning.

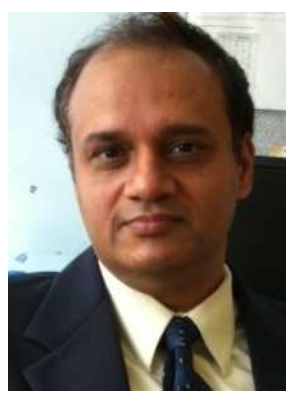

Vinaya Shukla is a Senior Lecturer in Operations and Supply Chain Management at Middlesex University Business School, London. He has a PhD from Cardiff Business School, UK. Prior to academia, he spent many years as a Management Consultant advising clients on how to improve their operations performance. His research interests are in Industry 4.0 and Blockchain, supply chain sustainability, supply chain systems and supply chain risk management. He has published in several prestigious journals including the International Journal of Production Economics, International Journal of Production Research, Supply Chain Management-An International Journal, Production Planning and Control, International Journal of Logistics Management \& Journal of Manufacturing Technology Management.

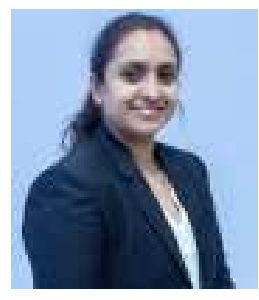

Shalini Manghat is a quality management professional with over a decade of experience in the Higher education sector in the United Arab Emirates. She has demonstrated expertise in the areas of quality assurance, institutional research, accreditation, policy development, strategic planning and writing comprehensive reports to meet the needs of internal and external stakeholders. She is also senior assessor for the Dubai Human Development Award (DHDA). She is currently pursuing a $\mathrm{PhD}$ in Higher Education from Lancaster University UK. 